University of California, Hastings College of the Law UC Hastings Scholarship Repository

Faculty Scholarship

2002

\title{
A Theory of Imperial Law: A Study on U.S. Hegemony and the Latin Resistance
}

Ugo Mattei

UC Hastings College of the Law, matteiu@uchastings.edu

Follow this and additional works at: http://repository.uchastings.edu/faculty_scholarship

Part of the International Law Commons

\section{Recommended Citation}

Ugo Mattei, A Theory of Imperial Law: A Study on U.S. Hegemony and the Latin Resistance, 10 Ind. J. Global Legal Stud. 383 (2002). Available at: http://repository.uchastings.edu/faculty_scholarship/511

This Article is brought to you for free and open access by UC Hastings Scholarship Repository. It has been accepted for inclusion in Faculty Scholarship by an authorized administrator of UC Hastings Scholarship Repository. For more information, please contact marcusc@uchastings.edu. 


\title{
UNIVERSITY of CALIFORNIA HASTINGS COLLEGE OF THE LAW
}

\section{Faculty Publications}

UC Hastings College of the Law Library

\author{
Author: Ugo Mattei \\ Source: $\quad$ Indiana Journal of Global Legal Studies \\ Citation: $\quad 10$ Ind. J. Global Legal Stud. 383 (2002). \\ Title: $\quad$ A Theory of Imperial Law: A Study on U.S. Hegemony and the Latin Resistance
}

Originally published in INDIANA JOURNAL OF GLOBAL LEGAL STUDIES. This article is reprinted with permission from INDIANA JOURNAL OF GLOBAL LEGAL STUDIES and Indiana University Maurer School of Law. 


\title{
A Theory of Imperial Law: A Study on U.S. Hegemony and the Latin Resistance
}

\author{
UGO MATTE *
}

INTRODUCTION

This essay attempts to develop a theory of imperial law that is able to explain post-Cold War changes in the general process of Americanization in legal thinking. My claim is that "imperial law" is now a dominant layer of world-wide legal systems. ${ }^{1}$ Imperial law is produced, in the interest of international capital, by a variety of both public and private institutions, all sharing a gap in legitimacy, sometimes called the "democratic deficit." Imperial law is shaped by a spectacular process of exaggeration, aimed at building consent for the purpose of hegemonic domination. Imperial law subordinates local legal arrangements world-wide, reproducing on the global scale the same phenomenon of legal dualism that thus far has characterized the law of developing countries. Predatory economic globalization is the vehicle, the all-mighty ally, and the beneficiary of imperial law. Ironically, despite its absolute lack of democratic legitimacy, imperial law imposes as a natural necessity, by means of discursive practices branded "democracy and the rule of law," a reactive legal philosophy that outlaws redistribution of wealth based on

\footnotetext{
* Alfred and Hanna Fromm Professor of Intemational and Comparative Law, U.C. Hastings; Professore Ordinario di Diritto Civile, Università di Torino. J.D. University of Turin (1983); LLM, Boalt Hall U.C.Berkeley (1989). This article has been produced to be discussed at the Indiana Global Law Symposium (April 5 2002) and at the Harvard Critical Globalization Conference (April 12 and 13,2002). I have delivered this article at a variety of workshops and conferences including the Conference on Americanization of legal thought held in Paris (Archives de Philosophie du Droit, June 2000); the Max Plank Institute (Hamburg, Germany May 2002); Stanford University (October 2001), the Department of Anthropology of U.C. Berkeley (September 2001) and the University of Florence (April 2002). I wish to thank Professors Alfred Aman, for inviting me at Indiana; Professor David Kennedy for inviting me at Harvard; Professor Jurgen Basedow for the Max Plank; Professor Horatia Muir Watt for Paris; Professor Vittoria Barsotti for Florence. I wish also to specially thank, for comments, reactions and encouragement on early versions: Duncan Kennedy, George Fletcher, Vincenzo Varano, Mauro Bussani, Elisabetta Grande, Hans Baade, Anna di Robilant, Laura Nader, Diego Lopez Medina, James Gordley, Mariella Pandolfi, and David Trubeck.

1. As a layer of the law, imperialism can be studied by methodologies such as those invoking legal pluralism. See generally Marco Guadagni, Legal Pluralism, in THE NEw PALGRAVE: A DictionaRy OF ECONOMICS AND THE LAW 542 (Peter Newman ed., 1998) [hereinafter THE NEW PALGRAVE]. For a theory of legal pluralism in the process of globalization, see F.G. Snyder, Governing Globalization, in TRANSNATIONAL LEGAL PROCESSES: GLOBALIZATION AND POWER DISPARITIES 65 (Michael Likosky ed., 2002) [hereinafter TRANSNATIONAL LEGAL PROCESSES].
} 
social solidarity. ${ }^{2}$ At the core of imperial law there is U.S. law, as transformed and adapted after the Reagan-Thatcher revolution, in the process of infiltrating the huge periphery left open after the end of the Cold War. A study of imperial law requires a careful discussion of the factors of penetration of U.S. legal consciousness world-wide, as well as a careful distinction between the context of production and the context of reception ${ }^{3}$ of the variety of institutional arrangements that make imperial law. Factors of resistance need to be fully appreciated as well.

\section{AMERICAN LAW: FROM LEADERSHIP TO DOMINANCE}

The years following the Second World War have shown a dramatic change in the pattern of world hegemony in the law. Leading legal ideas, once produced in Continental Civilian Europe and exported through the periphery of the world, are now for the first time produced in a common law jurisdiction: the United States. ${ }^{4}$ There is little question that the present world dominance of the United States has been economic, military, and political first, and legal only in a more recent moment, so that a ready explanation of legal hegemony can be found with a simple Marxist explanation of law as a superstructure of the economy. ${ }^{5}$ Nevertheless, the question of the relationship between legal, political, and economic hegemony is not likely to be correctly addressed within a cause-and-effect paradigm. ${ }^{6}$ Ultimately, addressing this question is a very

2. This essay will not discuss the kind of redistribution (in favor of the winners) that is fostered by economic globalization and by its violent re-structuring of capitalism. For the best recent discussion available on this different kind of redistribution, see generally WILLIAM K. TABB, THE AMORAL ELEPHANT: GLOBALIZATION AND THE STRUGGLE FOR SOCIAL JUSTICE IN THE TWENTY-FIRST CENTURY (2001). Every deep transformation in processes of production through history implies redistribution of wealth across social classes in favor of the winners. See KARL POLANY, THE GREAT TRANSFORMATION: THE POLITICAL AND ECONOMIC ORIGINS OF OUR TIME (1944). In this essay, however, I will talk of redistribution in the sense of favoring social solidarity, and therefore aimed at more equality.

3. On this useful theoretical distinction, see Diego Lopez Medina, Comparative Jurisprudence (2000) (unpublished J.S.D. dissertation, Harvard Law School) (on file with author).

4. Mirroring this phenomenon, new continental philosophical ideas were incorporated and produced in the United States by 1969 with Jacques Derrida's seminal lectures at Johns Hopkins University. See generally JACQUES DERRIDA, MARGNS OF PHILOSOPHY (Alan Bass trans., Univ. of Chicago Press 1982) (1972).

5. See generally 3 KARL MARX, CAPITAL: A CRITIQUE OF POLITICAL ECONOMY (David Fembach trans., Penguin Books 1981) (1867).

6. Comparativists are familiar with the discussion between Watson and Friedman on whether law can correctly be perceived as a response to social needs. The basic arguments for the opposite positions are set foreward in ALAN WATSON, LEGAL TRANSPLANTS: AN APPROACH TO COMPARATIVE LAW (1974); W. FRIEDMANN, LAW IN CHANGING SOCIETY (1959). 
important area of basic jurisprudential research because it reveals some general aspects about the nature of law as a device of global governance.

Observing historical patterns of legal hegemony allows us to critique the distinction between two main patterns of governance through the law (and of legal transplants). ${ }^{7}$ Scholars of legal transplants have traditionally distinguished two patterns. The first is law as dominance without hegemony, in which the legal system is ultimately a coercive apparatus asserting political and economic power without consent. This area of inquiry and this model have been used to explain the relationship between the legal system of the motherland and that of the colonies within imperialistic colonial enterprises. The opposing pattern, telling a story of consensual voluntary reception by an admiring periphery of legal models developed and provided for at the center, is usually considered the most important pattern of legal transplants. It is described by stressing on the idea of consent within a notion of "prestige."

Little effort is necessary to challenge the sufficiency of this basic taxonomy in introducing legal transplants. Law is a detailed and complex machinery of social control that cannot function with any degree of effectiveness without some cooperation from a variety of individuals staffing legal institutions. These individuals usually consist of a professional elite which either already exists or is created by the hegemonic power. Such an elite provides the degree of consent to the reception of foreign legal ideas that is necessary for any legal transplant to occur. Hence, the distinction between imperialistic and nonimperialistic transplants is a matter only of degree and not of structure. In order to understand the nature of present legal hegemony, it is necessary to capture the way in which the law functions to build a degree of consent to the present pattern of international economic and political dominance. ${ }^{9}$

In this essay I suggest that a fundamental cultural construct of presumed consent is the rhetoric of democracy and the rule of law utilized by the imperial model of governance, ${ }^{10}$ triumphant worldwide together with the neo-American

7. The literature on legal transplants is now very extensive. See, e.g., ALAN WATSON, LEGAL TRANSPLANTS: AN APPROACH TO COMPARATIVE LAW (1974).

8. For a critical discussion, see ElISABETTA GRANDE, IMITAZIONE E DIRITTO: IPOTESI SULLA Circolazione deI MODElll (2001). See also MARTIN HEIDEGger, THE Question CONCERNING TECHNOLOGY AND OTHER ESSAYS 135, 153 (William Lovitt trans., 1977) (noting a similar pattem in his continental philosophy).

9. Cf. William I. Robinson, PRomoting POlyarChy: Globalization, U.S. INTERVENTION, AND HEGEMONY $21-25$ (1996) (providing a similar methodology in political science).

10. See generally MICHAEL HARDT \& ANTONIO NEGRI, EMPIRE (2001) (developing and discussing the idea of imperial governance). See also MICHEL ALBERT, CAPITALISM VS. CAPITALISM: How AMERICA'S 
model of capitalism developed by the Reagan and Thatcher revolution early in the 1980s. I argue that the last twenty years have produced the triumph in global governance of reactive, politically irresponsible institutions, such as the courts of law, over proactive politically accountable institutions such as direct administrative apparatuses of the State. ${ }^{11}$

This essay attempts to open a radical revision of some accepted modes of thought about the law as they appear today, at what has been called "the end of history." 12 Its aim is to discuss some ways in which global legality has been created in the present stage of world-wide legal development. It will show how democracy and the rule of law, in the present legal landscape, are just another rhetoric of legitimization of a given international dynamic of power. It will also denounce the present unconscious state in which the law is produced and developed by professional "consent building" elites. The consequences of such unconsciousness are creating a legal landscape in which the law is "naturally" giving up its role of constraining opportunistic behavior of market actors. This process results in the development of faked rules and institutions that are functional to the interests of the great capital and that dramatically enlarge inequality within society. I predict that such a legal environment is unable to avoid tragic results on a global scale such as those outlined in the well-known parable of the tragedy of the commons. ${ }^{13}$

My object of observation is a legal landscape in transition. I wish to analyze this path of transition from one political setting (the local state) to another political setting (world governance) in which American-framed reactive institutions are asserting themselves as legitimate and legitimating governing bodies, which I call imperial law. Imperial law is the product of a renowned alliance between state and economic institutions, a cooperative game in which a very limited number of powerful players are at play. ${ }^{14}$ While in the ages of colonialism such political battles for international hegemony were mostly carried on with an open use of force and political violence (in such a way that final extensive conflict between superpowers was unavoidable), in the age of

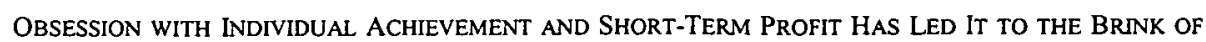
COLLAPSE 16 (Paul Haviland trans., 1993) (using the expression "neo-American" economic model). For a discussion of Albert's theory as applied to legal transplants, see infra notes 199-203 and accompanying text.

11. See WilliaM K. TABB, supra note 2, at 17-22 (discussing the difference between political and economic globalization).

12. See generally FRANCIS FUKUYAMA, THE END OF HISTORY AND THE LAST MAN (1992) (introducing successfully the fortunate, but highly misleading expression "the end of history").

13. See Garrett Hardin, The Tragedy of the Commons, 162 SCIENCE 1243, 1244 (1968).

14. See generally SuSAN GeORGE, REMETTRE LE OMC À SA PLACE (2001). 
globalization and of economic Empire political violence has been transformed into legal violence.

\section{DEVELOPING OUR TOOLS}

\section{A. Hegemony and Counter-Hegemony: From Gramsci to the Empire}

My study of legal imperialism builds on Antonio Gramsci's notion of hegemony. ${ }^{15}$ Gramsci defines hegemony as power reached by a combination of force and consent. Power cannot be reached only by brute force; it needs to be imposed by individuals that voluntarily accept government. Building on this suggestion, Louis Althusser has suggested that force is the province of the repressive apparatuses of the state like the army and the police, while consent is gained by means of what he called the ideological apparatuses of the state like schools, churches, or media. ${ }^{16}$ Such ideological apparatuses make hegemony more acceptable and at the same time make ideology a cross-class concept, thus going beyond the narrow Marxist idea of ideology as a classspecific device. ${ }^{17}$ Hegemony is therefore reached at least in part by a diffusion of power (needed in order to gain consensus) between a plurality of individuals. Such diffusion of power becomes a key concept in Michel Foucault's refutation of the idea of hegemony as a top-down imposition of power. Through his work, Foucault conceived of power as a relational position inherent in the very posture of every individual in society which, in turn, is determined by the socalled discursive practices. ${ }^{18}$

Diffusion of power carries as a consequence the birth of counter-hegemony, itself a powerful tool to defeat top-down attempts of hegemony. French critical thinker Gui Debord focuses on the impact of media and new communicative

15. Hegemony has been a key concept in Gramsci's reflections. It has been developed, outside of any systematic effort, throughout his work. See generally ANTONIO GRAMSCI, SELECTIONS FROM THE PRISON NOTEBOOKS OF ANTONIO GRAMSCI (Quintin Hoare \& Geoffrey Nowell Smith eds. \& trans., 1971); see also generally AN ANTONIO GRAMSCI READER: SELECTED WRTINGS, 1916-1935 (D. Forgacs ed., 1988) (providing a good selection of Gramsci's work).

16. LOUIS ALTHUSSER, LO STATO ED I SUOI APPARATI (1997).

17. See LOUIS ALTHUSSER, LENIN AND PHILOSOPHY AND OTHER EsSAYS (Ben Brewster trans., 1971); see also LOUIS ALTHUSSER \& E. BALIBAR, READING CAPITAL (1997) (discussing the full-fledged overtaking of ideology as a class-specific device).

18. Michel Foucault, ARChaeology OF KNOWledge (Alan M. Sheridan Smith trans., Routledge 1989) (1972). The basic notions approached in the text, however, have been developed throughout Foucault's massive scholarly production. See generally, e.g., MiCHEL FOUCAULT, THE FOUCAULT READER (Paul Rabinow ed., 1984). 
technology on human behavior and develops the notion of the individual as spectator and consumer within what he defines as the "spectacle society." Maintaining the Marxist tradition of focusing on the actual means of production that determine the organization of society, Debord demonstrates that "the spectacle" is not a marginal aspect of the post-modern society. Rather, it determines its very economic structure, capable of transforming the exploited proletariat into a much courted "consumer." 19 The proletariat is not considered only as labor force. In a notion that is developed also by French sociologist Baudrillard, the consumer is a worker who does not know to work. ${ }^{20}$ Understanding the "spectacle" allows a better understanding of present-day American hegemony.

The ways in which patterns of law have been historically exported can be captured within a variety of models. A first model is direct imperialistic/colonial rule, or imposition of legal patterns by military force, as it happened during times of military conquest (i.e. the Napoleonic Code imposed in Belgium; McArthur's reforms in post-World War II Japan, and so forth). This notion of imposition by force needs to be qualified, by taking into the account the structural need for institutional staffing and for cooperation of institutional actors to make a system work. ${ }^{21}$

A second model can be described as imposition by bargaining, in the sense that acceptance of a legal model is part of a subtle blackmail. ${ }^{22}$ Targeted countries are persuaded to change the law according to Western standards in order to get access to the international market and to remain economically viable. History offers examples of this model in China, Japan, and Egypt early in the last century, and today, this is the most important way in which the World Bank, International Monetary Fund, World Trade Organization, and European Union operate through the developing and former socialist world.

19. This transformation of the proletarian into a consumer not only updates but also radically transforms the way in which Marxist theory works. Revolutionary ideologist Luckacs's notions of commodification, reification and, in particular, contemplation are used by Debord to see how the once exploited proletarian and now consumer is persuaded by the structure of the show of the existence of a "second nature." See GUY DEBORD, THE SOCIETY OF THE SPECTACLE 25 (Donald Nicholson-Smith trans., Zone Books 1995) (1977) (citing GEORG LUKÁCS, HISTORY AND CLASS CONSCIOUSNESS: STUDIES IN MARXIST DIALECTICS (Rodney Livingstone trans., Merlin Press 1971) (1968)).

20. JEAN BAUDRILLARD, THE CONSUMER SOCIETY: MYTHS AND STRUCTURES 14-18 (Chris Turner trans., Sage Publications 1998) (1970).

21. See supra note 9 and accompanying text.

22. See Sally Falk Moore, An International Legal Regime and the Context of Conditionality, in TRANSNATIONAL LEgal PROCESSES, supra note 1, at 333 (describing the model also as "context of conditionality"). 
A third model, constructed as fully consensual, has been presented as diffusion by prestige, focusing on a deliberate process of institutional admiration that leads to the reception of law. ${ }^{23}$ My claim is that the process of Americanization in the last few years can only be understood within a clear perception that ideological apparatuses are at play, producing spectacular propaganda that allows the produced legal consciousness to circulate.

These preliminary remarks show some shortcomings of the comparative discussions of legal transplants that proceed outside of the analytical framework of hegemony and counter-hegemony. Indeed, the hegemony/counter-hegemony framework is crucial to understanding that force can never by itself be sufficient; it always needs a more or less extensive degree of institutional consent to operate. What is even more important is that the framework allows us to perceive the naively anthropomorphic nature of most traditional analyses. Legal transplants cannot be seen as happening as the result of the choice of one mind that freely or coactively receives the produced model. Both in the phase of production and in the phase of reception, legal transplants are a lively dialectic between consent and dissent, between hegemonic and counterhegemonic forces, between mainstream and critical approaches. In other words, dominant and dominated positions have to be considered in the picture because they allow an understanding of the high complexity of the picture.

\section{B. Reactive Institutions as the Fundamental Structure of U.S. Law}

In previous papers, I have outlined the fundamental structure behind what I called "the rule of professional law" and the historical reasons for current American intellectual leadership in the world's legal landscape. ${ }^{24}$ The fundamental structure of American law has unfolded to become a politically legitimized system in which straight political power is counterbalanced by a double set of professional (counter-majoritarian) checks. Such a system is the result of imports from Europe digested and made spectacular by way of "exaggeration" in the United States.

23. See WaTSON, supra note 7; see also Rodolfo Sacco, Legal Formants: A Dynamic Approach to Comparative Law, 39 AM. J. COMP. L. 343, $397-400$ (1991) (introducing the notion of prestige); GRANDE, supra note 8 (discussing the notion of prestige).

24. See Ugo Mattei, Three Patterns of Law: Taxonomy and Change in the World's Legal Systems, 45 AM. J. COMP. L. 5 (1997) (explaining the rule of professional law) [hereinafter Three Patterns of Law]; Ugo Mattei, Why the Wind Changed: Intellectual Leadership in Western Law, 42 AM. J. COMP. L. 195 (1994) (explaining U.S. leadership). 
By the early part of the last century (a century significantly labeled "the American century") ${ }^{25}$ U.S. law had already received from Europe, and digested in a genuinely original way, the fundamental components of its legal structure. The English common law tradition has transmitted to the former colony the ideal of judges as oracles of the law and of a strong, independent judiciary as the institutional framework in which judges can perform their role of guardians of individual rights. American law has developed this legacy and "exaggerated" it to the point of inventing constitutional adjudication. Judges are not only the oracles of the law and the leaders of the professional legal system; they also have the power to declare, in the process of adjudication, political decisionmaking as unconstitutional. ${ }^{26}$ Because of such outstanding extension of judicial power within American law, the belief, already noticed by Tocqueville, ${ }^{27}$ that any political problem can sooner or later be decided by a court of law has been carried to its symbolic extreme in the Nuremberg Trials, and possibly to its very limit in Bush v. Gore. ${ }^{28}$

The civil law tradition has also transmitted some fundamental modes of thought that U.S. law has been busy expanding and exaggerating through the nineteenth and twentieth centuries. France has conveyed to the United States the idea of universal individual rights. These "negative" rights of first generation have been enshrined in the U.S. Constitution, influential as they were on the majority of the founding fathers. ${ }^{29}$ Not only has this universalistic

25. See, e.g., OLIVIER ZUNZ, PERCHÉ IL SECOLO AMERICANO? [WHY THE AMERICAN CENTURY?] (2002); see also, e.g., ERIC HOBSBAWM, AGE OF EXTREMES: THE SHORT TWENTIETH CENTURY, 1914-1991 15 (1994). See generally GIOVANNI ARRIGHI, THE LONG TWENTIETH CENTURY: MONEY, POWER, AND THE ORIGINS OF OUR TIMES (1994).

26. See Marbury v. Madison, 5 U.S. 137, 178 (1803).

27. ALEXIS DE TOCQUEVILLE, DEMOCRACY IN AMERICA, (Richard D. Heffner ed., Signet Classic 2001) (1956). Very recently, an important book has discussed "adversarial legalism," something similar to my idea of "reactive institutional setting," as the "American way of law." See ROBERT A. KAGAN, ADVERSARIAL LEGALISM: THE AMERICAN WAY OF LAW (2001). Kagan's work builds and expands, beyond the limits of procedure, important and influential ideas set forward in comparative law by Damaŝka some time ago. See MIRJAN R. DAMAŜKA, THE FACES OF JUSTICE AND STATE AUTHORTYY: A COMPARATIVE APPROACH TO THE LEGAL PROCESS 73-80 (1986). My arguments carry the point forward. The "reactive way" cannot be seen as a mere feature of American law, but is actually the fundamental philosophy of globalization that, as a new layer of legal systems forms worldwide, pushes for a complex variety of processes of privatization of the legal system.

28. See Rachel E. Barkow, More Supreme than Court? The Fall of the Political Question Doctrine and the Rise of Judicial Supremacy, 102 CoLUM. L. REV. 237 (2002). See generally Michael J. Klarman, Bush v. Gore Through the Lens of Constitutional History, 89 CAL L. REV. 1721 (2001) (providing a discussion of the decision in light of legal history); 65 LAW \& CONTEMP. PROBS. 1 -95 (2002) (providing a general discussion by several authors).

29. See generally JOSEPH J. ElLIS, FOUNDING BROTHERS: THE REVOLUTIONARY GENERATION (2002) (providing a recent, fascinating discussion of the credo and ideology of the Founding Fathers). 
ideal been carried to the extreme, as witnessed among other things by notions of universal jurisdiction of U.S. courts in the vindication of such rights, ${ }^{30}$ but negative rights, in the absence of thick notions of sovereignty and statehood developed by the Jacobeans, became a genuine limit to the redistributive activity of the American state. Notions of freedom from government intrusion were by no means limited to judicial lawmaking in the Lochner era. A strong limit to any proactive activity of government, except in areas such as defense, can be seen as the result of French-inspired notions of (economic) rights.

Also, Germany has transmitted to the United States one of its fundamental present-day characteristics: the presence of strong, independent academic institutions as another source of professional check on the political process. It was only because the law was considered a science that it was natural to argue for its teaching in university contexts. Otherwise it could well have remained a practical business, as it continued to be in England until well after the Victorian age. American law schools (professional schools staffed with faculty that regard themselves as academic scholars) are the only ones in the world that offer basic legal education at the graduate school level. Consequently, and paradoxically for a system based on "professional schooling," the average American lawyer is exposed to more years of academic training that any other colleague in the world. Moreover, because of this further exaggeration as compared to academic undergraduate legal education in Europe, American academia can well be seen today as the global lawyer's graduate school in the sense that ambitious lawyers worldwide complete their undergraduate legal education in the United States. ${ }^{31}$

There is another fundamental structure of U.S. law that, in my opinion, makes it better suited to the framework of the global market: its high degree of decentralization. This is possibly the most original aspect of the fundamental structure of U.S. law. No other legal system in the world has developed a fullfledged federal judicial system as complete and sophisticated as the United States has. The co-existence of a large number of federal and state courts made issues of jurisdiction and choice of law the primary concern of the American legal profession. These are the same issues that are on the table of the lawyer approaching global problems. American lawyers already enjoy a legal culture and discourse that is broader than jurisdictional limits. In this scenario, the

30. See discussion infra Part VII.

31. See Wolfgang Wiegand, The Reception of American Law in Europe, 39 AM. J. CoMP. L. 229, 233-35 (1991) 
annexing of one more jurisdiction, wherever located, does not particularly change the U.S. lawyer's way of reasoning.

The very structure of the American judicial process, moreover, decentralizes power and activity. A large variety of activities within litigation which are labeled "official" in European legal systems, such as service of process, discovery, and questioning of witnesses, are already private matters in American law. ${ }^{32}$ This powerful combination of adaptive forces makes the structure of American law sufficiently familiar so as not to be excessively feared, ${ }^{33}$ yet sufficiently ambiguous to be successful in the international legal landscape. ${ }^{34}$

Another crucial aspect of American hegemony is the equation between democracy and elections. The majority rule principle, quite uncritically embraced in the United States, appears natural and obvious as long as we compare it to its absurd opposite, that of the minority rule. But if we think to how numerous and various can be the means to give to a group a unitary will we should ask whether Sumner Maine was not right when claiming that the majority rule is the most artificial between all those available. ${ }^{35}$ The majority rule as expressed by elections has institutionalized in the United States the notion of a market for votes that carries as a structural consequence a high degree of spectacular selection of leadership, mostly determined by media control and availability of extensive economic means.

It is important to the present analysis to observe the way in which these basic European institutional factors have been carried to the extreme and thus "exaggerated" in the United States. Judges develop as full-fledged supervisors of the direct political process. Individual rights develop an unprecedented universal jurisdictional reach. Lawyers develop highly technocratic skills of social engineering. Elections, along with media power, defeat political parties as laboratories of political consent and as agencies leading to the reduction of class differences.

32. See Rudolf B. Schlesinger et AL., COMPARATIVE LAW 428, 448 (6th ed. 1998).

33. On discovery and "fishing expeditions" as spectacular practices resented in Europe, see the discussion infra notes $150-51$ and accompanying text.

34. See Globalizations and Social Movements: Culture, Power, and the Transnational PUBLIC SPHERE (John A. Guidry et al. eds., 2000); see also Duncan Kennedy, Three Globalizations (January 2003) (paper delivered at the Harvard Globalization Symposium, forthcoming on Suffolk University Law Review) (discussing political ambiguity as an explanation for worldwide success of a legal pattern).

35. See luciano Canfora, Critica della Retorica Democratica (2002); see also Edoardo RUFFINI, LA RAGIONE DEI PIU:: RICERCHE SULLA STORIA DEL PRINCIPIO MAGGIORTARIO (1977); H. SUMNER MANE, ETUDES SUR L'HISTOIRE DES INSTITUTIONS PRIMITIVES (Emest Thorin ed., 1880). 
As shown in the previous section, U.S. law has been able to become the "extreme West" of the Western legal tradition ${ }^{36}$ whose fundamental notions are plainly and structurally incompatible with alternative ideas such as, for example, "Socialist legality" or "Islamic jurisprudence." Countries which embrace or have embraced these radically alternative views have always been located at the "periphery" of the free world. Interestingly, even those countries such as European democracies, traditionally located at the center, have been gradually pushed to the periphery in the building process of global governance by a constant erosion of the activist philosophies of their sovereign states. The less than full development of decentralized reactive institutions has been singled out as a problematic factor, even in the European context. The new periphery, just as much as the traditional one, maintains certain legal factors that are an irritant for an American-inspired global legal consciousness.

From the very aftermath of World War II, it became quite apparent that the notion of sovereignty and statehood developed in the civil law was exposed to a strong structural critique. The notion, enshrined in the Hegelian philosophical tradition, that the State was an organ pursuing its own sovereign interest, ontologically different and occasionally incompatible with the aggregate of the individual rights of its subjects, was in many quarters made accountable for the trashing of the rule of law in fascist Europe. An alternative vision of sovereignty was found in the notion that the State was nothing more than "the government in office" (typical of the pragmatic Anglo-American tradition), pursuing an interest that had to coincide with the aggregate of individuals' interests, and whose activity was to be limited to this function by technocratic checks.

The roots were established for the "naturalization" of the American way, and for its fundamental challenge to the hierarchical relationship between the political process and free (market) activity. Such process of naturalization of the institutional setting of the free world was started in America in 1952 by President Eisenhower's conservative political platform that defeated President Truman's Fair Deal. Reinforced through the Cold War as a polemic towards socialism, the suspicion of activist redistributive policies and of government intervention in matters other than defense constantly controlled American politics and, through its influence, the present posture of the international financial institutions.

36. See JEAN PHILIPPE MATHY, EXTREME OCCIDENT: FRENCH INTELLECTUALS AND AMERICA (1993). 
Local American scholarly evolutions made the prestige of U.S. law felt by legal professionals worldwide, so that the intellectual leadership of American law is now an undisputable fact. The years of the Cold War and the demise of western legality that has characterized most of the communist regimes in the U.S.S.R. orbit of influence have confirmed the perceived benefits of the three fundamental symbols of the American rule of law: spectacular elections (a sort of advertising spot for democracy), independent judiciary (with highly spectacular interventions in U.S. political life), and free and creative academic critique of the political and of the judicial process. None of these tenets was characteristic of the Soviet bloc, so the imposition of such fundamental characteristics became the recipe for change in the aftermath of the fall of the Soviet Republic.

\section{HEgEMONY AND THE CONSTRUCTION OF THE FoE: THE REPRESSIVE INSTITUTION OF GLOBAL GOVERNANCE}

The last ten years of the last century have been crucial to the refinement of imperialistic and hegemonic aspects of American law. Nobody has put it more clearly, though moderately, than leading international lawyer Richard Falk:

The logic of hegemonic authority extends beyond the implications of unequal power and influence to encompass the rather amorphous, yet significant, role of "global leadership." Such a hegemonic role in an era of moderated international conflict is premised on military power. But also crucially important is a normative reputation as a generally benevolent political actor and a provider of order beneficial for the global public good, not just for the national interests of the hegemon. ${ }^{37}$

The very same rhetoric of freedom has guided U.S. international interventions from World War II to the present ideological construction of the Islamic world (represented by Komeini, Saddam, and the Taliban) as the living denial of the kind of universal freedom, based on gender equality and universal human

37. Richard Falk, Re-framing the Legal Agenda of World Order in the Course of a Turbulent Century, in TRANSNATIONAL LEGAL PROCESSES, supra note 1 , at 355, 369. 
rights, that is inextricably connected with the neo-liberal capitalist model of development. ${ }^{38}$

The nineties were the decade in which U.S. power (and consequently, law) turned from leadership to hegemony. Most western communist and socialist parties have started a major self-critique, and leftist intellectuals' discovery of the virtues of the market has provided some quite extreme attitudes. ${ }^{39}$ The end of the Cold War has been depicted by many commentators as an endogenous phenomenon within the socialist world. The highly proactive political apparatus of the soviet "concentrated spectacle," to use Debord's notion, ${ }^{40}$ simply could not resist processes of internal corruption accelerated by the sense of freedom and by dynamics of opportunism that were precluded from any socially beneficial spillover effect. This is, however, a very simplistic vision of the fall of the Soviet Empire. A variety of other factors must be considered too: exogenous factors such as technological competition (e.g. the Star Wars system of the Reagan administration) that created an unbearable economic pressure for the Socialist State, ${ }^{41}$ and the undisputable spectacular appeal of the consumer's society, made accessible to would-be consumers by enhanced media reach. What is important to point out is that technological evolutions were the protagonists of most of these and other relevant events. And military as well as media technology became the creed of the next step in the development of global ideology: the sense that technology can defeat demography. This notion

38. See SAMUEl P. Huntington, THE Clash of CIVIllzations AND the REMAKING of WORLd ORDER (1996) (discussing the construction of a new confrontation, substituting Islamism for the Cold War); $c f$. MICHEL FOUCAULT, POLITICS, PHILOSOPHY, CULTURE, AND OTHER WRITINGS (1988) (providing a similar idea from a post-structuralist perspective).

39. The shift of leftist paradigms to notions compatible with the official dogma of neo-liberalism is usually associated with Toni Blair's New Labour. For the intellectual rationalization of this evolution, see A. Giddens, THE THIRD WAY: THE ReNEWAL OF SOCIAL DEMOCRACY (1998). The consequences of refusal to adapt to the new post-Cold War economic policy are best appreciated by considering the forced resignation of Chancellor Oskar Lafontaine in 1998, substituted by the "new leftist" paradigm of Chancellor Schroeder for the same party. See Falk, supra note 37 , at page 370 n. 51 .

40. GUI DEBORD, COMMENTARI ALLA SOCIETÀ DELLO SPETTACOLO [COMMENTS ON THE SOCIETY OF THE SPECTACLE] (Malcolm Imrie trans., Verso Books 1998) (1997).

41. Factors of resistance against the Soviet empire, such as religion in many of its Islamic provinces and the Afghanistan war, readily tumed into a Soviet Vietnam, also account for the final collapse. See BRUNO BONGIOVANNI, STORIA DELLA GUERRA FREDDA (2001) (emphasizing notions of terror balance and containment as key realist notions in Cold War intemational relations). See generally FROM COLD WAR TO COLLAPSE: THEORY AND WORLD POLITICS IN THE 1980S (Mike Bowker \& Robin Brown eds., 1993). 
has determined, among other things, the politics and ideology of immigration law through the West. ${ }^{42}$

With "enemy number one" defeated, it became almost immediately apparent that socialism was not the only radically incompatible alternative to the Western institutional setting. American foreign policy did not need to change much, since its technological presence ${ }^{43}$ was still required by its European allies, whose internal political landscape constantly and incrementally turned to the right. ${ }^{44}$ By the early nineties, the socialists had been defeated in France, Italy, Spain, and Greece. In Scandinavian countries, the socialdemocratic experiment was facing a tremendous and perhaps irreversible crisis. In Russia, the communists were forced to accept a spectacular electoral confrontation in which they would have no chance to win, given the technical skills of and the foreign aid to the opposite front. ${ }^{45}$ Notions of "third way" or "New Labour" witnessed a dramatic convergence of the European political landscape with the American counterpart. In the United States, at least since the "Great Society," the differential in class representation between the Democrats and the Republicans was blurred. President Clinton and Prime Minister Blair have been the icons of the political establishment and the long wave of the conservative revolution well beyond the political platform of the Republicans and the Tories.

A culture of exclusion and of assertion characterized Western domestic and foreign policy in the United States and, following its lead, in Europe. Zero tolerance for illegal immigration is now the common slogan of conservative governments and of their institutional oppositions throughout the West. ${ }^{46}$ Meanwhile, in the international arena, NATO could incrementally and dramatically change its nature. At the recent NATO summit with President

42. See generally The Great Globalization Debate: An Introduction, in THE GLOBAL TRANSFORMATIONS READER: AN INTRODUCTION TO THE GLOBALIZATION DEBATE (David Held \& Anthony McGrew eds., 2000) [hereinafter THE GLOBAL TRANSFORMATIONS READER].

43. This mental framework is reflected by "realist" paradigms in intemational law. See Falk, supra note 37 , at 357.

44. See John Gray, The Passing of Social Democracy, in THE GloBAL TRANSFORMATION READER, supra note 42 , at 328 .

45. Communist candidate Ziuganov's chances of victory were addressed by international advisors through the creation of a nationalist leader, General Lebed.

46. See Linda Bosniak, Critical Reflections on "Citizenship" as a Progressive Aspiration, in LABOUR LAW IN AN ERA OF Globalization: TRANSFORMATIVE PRACTICES AND POSSIBILITIES 339, 342 (Joanne Conaghan et al. eds., 2002) (noting that illegal immigrants are treated as "second class citizens"); see also C. Joppke, Sovereignty and Citizenship in a World of Migration, in TRANSNATIONAL LEGAL PROCESSES, supra note 1 , at 259 . 
Putin, the basis was set for a new strategic and offensive alliance for the further expansion of the free global market. NATO leaders and their former foes now share a new common enemy and a new common agenda. Within the notion of fundamentalist Islamic-originated terrorist activity, there is space for such different phenomena as the Chechenia resistance, the Middle Eastern war, and of course, the War on Terror so far carried out against Afghanistan, and threatened against Iraq, Iran, Sudan, Yemen, and Somalia.

NATO strikes in Bosnia, the Gulf War (Desert Storm), and Somalia (the Restore Hope mission) and, more recently, Enduring Freedom in Afghanistan have been the most visible recent instances in which the repressive institutions of the global society have had a chance to prove their strengths. Thousands of innocent people were killed while public opinion and media propaganda focused on the redress of international human rights that the strikes were guaranteeing. ${ }^{47}$ Some international law scholars now define the Bosnia NATO strikes as illegal. ${ }^{48}$ The Somali experience shows that areas that were not reached by the International effort of the U.N. Operation in Somalia (UNOSOM) are today well ahead of the others in the pacification process. ${ }^{49}$ The George W. Bush administration has introduced itself to the world by a similar campaign to enforce international law. The more recent "War on Terror" has confirmed the early attitude of the incumbent U.S. administration. Interestingly, all these actions have been carried on in contexts characterized by a hegemony of political law and/or traditional law within the deep characteristics of the legal system. ${ }^{50}$ All such interventions have been targeted towards societies in which professional law had always remained either absent or very superficial and in which democracy and the rule of law, as products of Western civilization/colonization, could be seen as deeply foreign to local conditions.

47. See SEAN D. MURPhy, Humanitarian INTERVENTION: THE UNited Nations IN AN EVOlVng WORLD ORDER 182-243 (1996).

48. Given that illegality is the rule rather than the exception, the tight language of the U.N. Charter outlawing aggressive war has always been considered utopian and unrealistic. See, e.g., WALTER MILLIS \& JAMES ReAL, THE ABOLITION OF WAR (1963); GRENVILlE Clark \& LOUIS B. SOHN, WORLD PEACE THROUGH WORLD LAW (3d ed.1966); RICHARD A. FALK, A STUDY OF FUTURE WORLDS (1975).

49. This is the case in Somaliland and Puntland State (both recently singled out by the Bush administration, however, as potential targets for anti-terrorism strikes). See Ugo Mattei, Patterns of African Constitution in the Making, in TRANSNATIONAL LEGAL PROCESSES, supra note 1, at 275, 282 (regarding the situation in Puntland).

50. For a taxonomy of legal systems based on a distinction between the rule of professional law, rule of political law, and rule of traditional law, see Three Patterns of Law, supra note 24. 
Islamic law has been able to claim a thorough degree of legitimacy by means of circuits of legitimization that are typical of non-western societies. ${ }^{51}$ In former Yugoslavia, the traditional gate between Islam and Christianity, effective centralized secular institutions were established in Tito's time. ${ }^{52}$ Nevertheless, during the communist era, legitimacy was never based on elections, and the Western notion of rule of law was substituted by a kind of socialist legality. The circuits of power legitimacy in former Yugoslavia were to be found more in notions of military leadership than otherwise. The rise of Milosevic to power and the Pan-Serbian dream cannot be explained much differently than as an episode of skillful charismatic leadership.

Somalia and Afghanistan have much in common, in addition to their strategic geographic position around the oil area. They are both traditionally decentralized societies and have both experienced processes of more thorough social penetration of Islam in recent times. They are both internally divided in ethnic polarization, but at the same time, both have strong national identities. Both countries are very far from any idea of legitimacy based on majority rule. They both lack a Westernized legal elite strong enough to be an effective professional competitor to traditional and political legitimization. The principle of group unanimity in legitimate rulemaking and of war as a legitimating factor of leadership are strong and fierce factors of resistance towards western notions of democracy, rule of law and individual human rights. ${ }^{53}$

Not much needs to be said of Iraq to show the fundamental incompatibility of its social structure with Western notions of legality and Western institutions. Iraq falls straight within notions of leadership and legitimacy that are very common in the area and that are deeply rooted (although at times much challenged) in Islam. Once again, arguing for Western democracy and the rule of law in a centralized Islamic society is only a display of Western-centric neocolonial arrogance.

The structure of power and the deep bases of legitimacy of the legal systems in these countries targeted by operations of war are shared by a majority of the countries on Earth. It is no excess of cultural relativism to

51. Islamic law has been a successful provider of "public goods" such as security, charity, and education in many places where the Western notion of State simply failed. See Ugo Mattei, Foreign Inspired Courts as Agencies of Peace in Troubled Societies: A Plea for Realism and for Creativity, 2 GLOBAL JURIST 1 (2002), at http://www.bepress.com/gj/topics/vol2/iss 1/artl.

52. See generally GIANNANTONIO A. BENACCHIO, LA CIRCOLAZIONE DEI MODELLI GIURIDICI TRA GLI SLAVI DEL SUD: SLOVENI, CROATI, SERBI (1995).

53. See generally Mattei, supra note 51. 
observe this simple fact. Nor is it foreign to Western notions of equality of treatment under the law to reflect on the one-sided way in which international law is enforced. ${ }^{54}$ In the global world, the repressive institutions are the same as they have always been - the power of weapons is the rule..$^{55}$ This is not, of course, the place to discuss and catalogue the many occasions on which repressive international institutions have policed and enforced the new world order, born after World War II and accomplished after the symbolic fall of the Berlin Wall. ${ }^{56}$ For the purposes of this discussion, we can assume that force, in the form of international military enterprises under U.S. leadership, is still the most important instrument for imposing the hegemony of Western values. ${ }^{57}$ Further, we can assume that much of the hegemonic position of the United States has been achieved by developing and accomplishing unchallenged primacy of physical strengths. ${ }^{58}$

Much more interesting, for our purpose, is to reflect on the ways in which political consent is reached around such use of force. Loyalty seems mandatory in the new global order. ${ }^{59}$ The discursive practices of the dominant realist international law culture are to be considered at least in part responsible for this phenomenon. ${ }^{60}$

\section{INTERNATIONAL LAW AS AN IDEOLOGICAL APPARATUS OF GLOBAL GOVERNANCE}

There is no doubt that international law has offered a rhetoric capable of justifying the use of force by the repressive apparatuses of global governance, and that therefore it has played the role of an ideological institution responsible

54. NOAM CHOMSKY, THE NEW MILITARY HuMANISM: LESSONS FROM KoSOvo 1-80 (1999) (critiquing this attitude); see also Falk, supra note 37. On the dangers of such a double standard for the role of international leadership, see TORBJøRN L. KNUTSEN, THE RISE AND FALL OF WORLD ORDERS (1999).

55. See generally ROBERT HARVEY, THE RETURN OF THE STRONG: THE DRIFT TO GLOBAL DISORDER (1995); see also generally JAMES MAYALL, THE NEW INTERVENTIONISM 1991-1994: UNITED NATIONS EXPERIENCE IN CAMBODIA, FORMER YUGOSLAVIA, AND SOMALIA (1996).

56. See A. MARK WeISBURd, USE OF FORCE: THE PRACTICE Of STATES SINCE WORLD WAR II (1997)

57. See Edward N. Luttwak, Give War a Chance, 78 FOREIGN AFF. 36 (1999) (espousing an extreme position on the right).

58. See generally Joseph S. NyE, Bound to LeAd: The ChangIng NATURE of AMERICAN Power (1990).

59. See Thomas M. Franck, Clan and Superclan: Loyalty, Identity and Community in Law and Practice, 90 AM. J. INT'L L. 359 (1996).

60. See Falk, supra note 37, at 357 (discussing "the self serving acceptance by policymakers of some variant of realism as the proper mode of thought pertaining to international relations"). 
for the idea that violence towards innocent people can be "legal," and that a war of destruction can be "fair." 61

The rhetorical device used in the process of repressing deviance has been a genuinely legal concept, that of "international human rights." doctrine of limited sovereignty in the interest of international human rights has threatened the traditional nature of international law as a decentralized system ${ }^{63}$ based on territoriality, and has advocated the need for centralization in order to make international law more similar to systems of national law. The International Criminal Court is the most advanced point of this shift. Ad hoc courts, such as the one presently used against former Yugoslavian president Slobodan Milosevic, are the product of an even more open use of international law as an ex post facto legitimating factor of war. ${ }^{64}$

Today we believe that international law is not natural but positive law, whose fundamental sources are treaties and customs. Tomorrow, we might believe that international law is a worldwide legal system grounded in uniformity and in commonly shared ideals of law and order. ${ }^{65}$ International codes, international courts and international jails are already claiming to be generally recognized and established. Many commentators already approach international politics as if such an international centralized legal system were in place. With such a system in place (assuming that it is in place), the transformation of war into police power follows as a matter of course. Hence sovereignty can be routinely addressed as deviance from a standard of legality grounded in U.S.-constructed international human rights. ${ }^{66}$

It is interesting to observe that this process in international law is just the opposite of the general trend in jurisprudence. Scholars are today observing the triumph of pluralism and decentralization as a consequence of the failures of

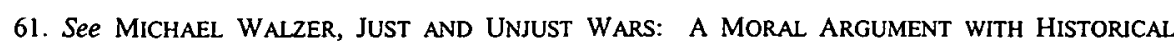
ILLUSTRATIONS 318 (1998); see also HARD CHOICES: MORAL DILEMMAS IN HUMANITARIAN INTERVENTION (Jonathan Moore ed., 1998).

62. See Richard Falk, The Quest for Human Rights in an Era of Globalization, in FUTURE MULTILATERALISM: THE POLITICAL AND SOCIAL FRAMEWORK 153, 157 (Michael G. Schechter ed., 1999).

63. See Hedley Bull, THE ANARCHICAL SOCIETY: A StUdy OF ORDER IN WORLd POlTICS (1977).

64. See M. Cherif Bassiouni \& Peter Manikas, The LaW of the INTERNational Criminal. TRIBUNAL FOR THE FORMER YUGOSLAVIA (1996).

65. See generally RICHARD FALK, LAW IN AN EMERGING GLOBAL VILLAGE: A POST-WESTPHALIAN PERSPECTIVE (1998).

66. See generally BEYOND WESTPHALIA? STATE SOVEREIGNTY AND INTERNATIONAL INTERVENTION (Gene M. Lyons \& Michael Mastanduno eds., 1995); see also STEPHEN D. KRASNER, SOVEREIGNTY: ORGANIZED HYPOCRISY (1999) (United States-centric critique of sovereignty); NOAM CHOMSKY, ROGUE STATES : THE RULE OF FORCE IN WORLD AFFAIRS 11, 124-55 (2000) (discussing the dangers of looking at the United States as a normative leader in intemational law). 
the legal monism advocated by state-centric positivism. A process of depositivization in jurisprudence is very clear. ${ }^{67}$ This can be seen as a cultural delay of international law, difficult to overcome but indeed in the process of being addressed by the best scholarship in the field. ${ }^{68}$

But the tool used to gain consensus, the doctrine of international human rights, is indeed very powerful, ${ }^{69}$ and has initiated the process of transformation of the very conception of international law developed after the birth of the modern nation-state. Such flourishing is however problematic because it provides a selective justification for intervention in the internal political business of all states that are not culturally aligned with Western law. ${ }^{70}$

Neo-colonial practices in the Third World are to a great extent originated by the evolution of advanced capitalism in the United States (what I have referred to as the neo-American model) and by its diffusion at the periphery within a reactive philosophy of governance that, outside of effective "reactive" institutions such as the one developed in the United States, paves the way to exploitive opportunistic behavior. ${ }^{71}$ Of course, it would be thoroughly inaccurate to see colonialism as a vehicle of Americanization. Only postcolonialism can be fairly seen as such. ${ }^{72}$ The unfolding of U.S. rule has indeed been a phenomenon that is better captured by the notion of imperialism than by that of outright colonialism. ${ }^{73}$

To begin with, imperialism is not limited as a relationship between "developed" and "developing," or between a colonizing nation-state and colonized people kept under foreign rule. An imperialistic desire attempts the

67. The pluralistic framework has been recently proposed to address issues of legal globalization. See Snyder, supra note 1.

68. See generally Falk, supra note 37.

69. Even in the U.S. the movement has been more or less benevolently criticized from a variety of perspectives. See, e.g., Ellen Messer, Anthropology and Human Rights, 22 ANN. REV. ANTHROPOLOGY 221 (1993) (surveying the (Anglophone) anthropological literature); see also Celina Romany, State Responsibility Goes Private: A Feminist Critique of the Public/Private Distinction in International Human Rights Law, in Human RIghtS OF WOMEN: NATIONAL AND INTERNATIONAL PERSPECTIVES 85 (Rebecca J. Cook ed., 1994).

70. See, e.g., L. Amede Obiora, Bridges and Barricades: Rethinking Polemics and Intransigence in the Campaign Against Female Circumcision, 47 CASE W. RES. L. REV. 275 (1997). See generally, BoAventura de SOUSA Santos, TOWARd a NEW COMMON SENSE: LaW, SCIENCE AND POLITICS IN THE PARADIGMATIC TRANSITION (1995).

71. See generally Richard Falk, PREdatory Globallzation: A CRITIQUe (1999).

72. See MARC FERro, COlONIZATION: A Global History (1997)

73. See generally P. Hirst, and G. Thompson, Globalization and the History of the International Economy, in THE GLOBAL TRANSFORMATION READER, supra note 42, at 274-86; see also generally WILLIAM ROBINSON, PROMOTING POLYARCHY-GLOBALIZATION, U.S. INTERVENTION AND HEGEMONY (1996). 
global imposition of its values and fundamental structures of government and modes of thought worldwide. In this sense, it is clear that communism has been an imperialistic attempt aiming at final worldwide success. Imperialism requires an "imperial ideal," a stronger ideological apparatus that can be reached only by means of strong and well-developed "ideological institutions."74 The ideals of a global market, of international human rights, of freedom throughout the world, and most notably of the "rule of law" perform this ideological role. ${ }^{75}$ Imperialism does not necessarily need to be a conscious effort, ${ }^{76}$ nor must it spell out an imperialistic doctrine, prescribing steps towards a final condition of imperial hegemony. ${ }^{77}$

The recent transformation of international law from a decentralized system of foreign sovereigns to a progressively more centralized legal system governed by professional elites staffing (international) courts of law is a more or less conscious reproduction of the reactive philosophy of the U.S. government by courts. As such, it is reproducing on the world scale a professional legal ideology of neutrality, democracy, and rule of law, granting legitimacy to the worldwide exercise of the United States's unprecedented political strength. Just as U.S. domestic doctrines of separation of powers, political questions, and sovereign immunity allow the U.S. government a quite extended and unnoticed degree of unrestricted power, ${ }^{78}$ similarly an international law governed by courts of law (on the Nuremberg model), rather than by negotiation between decentralized sovereign States, should produce the façade of legitimacy for the exercise of worldwide hegemony. Of course, the fear of counter-hegemonic use of such an international centralized legal system explains the reluctance of the U.S. government to support the International Criminal Court. ${ }^{79}$ The moment is ripe for introducing, within the legal field of international law, the notion of counter-hegemony as used in this article.

74. See HARDT \& NEGRI, supra note 10, at 17-20; Robert W. Cox, Gramsci, Hegemony and International Relations: An Essay in Method, 12 J. INT'L STUD. 162, 172 (1983).

75. On ideology, as with false consciousness, the classic is still KARL MARX \& FRIEDRICH ENGELS, L'IDEOLOGIA TEDESCA (1958).

76. It might also be rhetoric such as that used in the title of Nye's book, "Bound to Lead." See NYE, supra note 58. The question naturally rises: Who is binding whom?

77. See Maxwell O. Chibundu, Globalizing the Rule of Law: Some Thoughts at and on the Periphery, 7 IND. J. GLOBAL LEGAL STUD. 79 (1999).

78. See, for a discussion on the theory and practice of Sovereign Immunity, K. Nelson, Sovreign Immunity as a doctrine of Personal Jurisdiction, 115 HARV. L. REV. 1561 (2002).

79. See Harris Institute for Global Legal Studies, Should the United States Ratify the Treaty Establishing the International Criminal Court? (International Debate Series, 2002) (providing competing views for and against supporting the International Criminal Court). 


\section{INTERNATIONAL INTELLECTUAL PROPERTY AND COUNTER-HEGEMONY}

In addition to politics (and economics), technology is also a major source of institutional change. ${ }^{80}$ The nineties were also opened by the invention of the internet www protocol. It is worth noting, at least incidentally, that the internet originated from the need for speedy and secure communication of data to be used for military purposes during the Cold War years. It is therefore easy for conservative ideology to appraise it as a beneficial spillover of military research, and as convincing evidence of the need for allocation of yet more resources to the repressive apparatuses of the global governance, such as "star wars" projects. ${ }^{81}$

It is enough to browse the internet once to see its American cultural imprinting. The quantitative and qualitative advantage of U.S.-based English language sites is just another piece of evidence of the very strong cultural hegemony of the United States. ${ }^{82}$ The so-called "digital divide" is the virtual epiphany of the appalling growth of the difference between rich and poor countries, created and structured by another ideological apparatus of global governance: intellectual property. ${ }^{83}$ Information is today the most important source of wealth. Intellectual property, rooted in an extreme Western naturalistic notion of property law, is incompatible with fundamental communitarian values of non-Western societies. Western intellectual property is expanded worldwide through the internet and through the Trade Related aspects of Intellectual Property Rights (TRIPs). It formalizes the disparity of wealth and power that technology has been able to produce. ${ }^{84}$ The nonterritorial nature of intellectual property, as symbolized by the internet and the claim of universality and of objectivity of its justification, is producing more institutional change.

80. See generally David S. LANDES, The Unbound Prometheus: TeChNological Change AND INDUSTRIAL DEVELOPMENT IN WESTERN EUROPE FROM 1750 TO THE PRESENT (1969); see also generally FREDERICK M. ABBOTT \& DAVID J. GERBER, PUBLIC POLICY AND GLOBAL TECHNOLOGICAL INTEGRATION (1997).

81. There is abundant talk about the "American comparative advantage in technology" as a legitimating strategy. For a brilliant critical discussion with reference to many such hegemonic strategies, see Ruth Gana Okediji, Copyright and Public Welfare in Global Perspective, 7 IND. J. GloBAl LEGAL STUD. 117, 119 (1999).

82. See ARJUN APPADURA, MODERNITY AT LARGE: CULTURAL DIMENSIONS OF GloballzatION (1996).

83. See Ngaire Woods, Order, Globalization and Inequality in World Politics, in THE GLOBAL TRANSFORMATIONS READER, supra note 42 , at $387,389$.

84. This is a phenomenon that is by no means a novelty. See generally DANIEL R. HEADRICK, THE TOOLS OF EMPIRE: TECHNOLOGY AND EUROPEAN IMPERIALISM IN THE NINETEENTH CENTURY (1981). 
Global legitimacy of intellectual property is rooted in the notion that individual creativity deserves a prize and that exclusive property rights constitute such a prize. We are back to Locke and to natural law justifications of individualistic ownership. Nobody would farm without the guarantee of exclusive property of the outcome of his/her labor. Similarly, nobody would have incentives to create without intellectual property granting a monopoly on his/her creativity. Nobody would genetically modify seeds with no guarantee that the legal system would help to impose such technology on farmers worldwide, forcing them to abandon communitarian practices of seed sharing and swapping. ${ }^{85}$ Of course, such eighteenth-century rhetoric, reinforced today by simplistic neoclassical legal and economic models such as those used in mainstream law and economics literature ${ }^{86}$ denies notions of alienation and exploitation, and the simple fact that intellectual property rights freeze the status quo rather than promoting innovation and change. ${ }^{87}$

The general universalistic individual-centered philosophy propagated by intellectual property and by the institutions created to enforce it worldwide (World Intellectual Property Organization, TRIPs, and so forth) ${ }^{88}$ serves the purpose of redefining territorial ideas of sovereignty to be more functional to the needs of the Empire and of the big corporate actors. ${ }^{89}$ The hegemonic aspects of the intellectual property revolution are easy to perceive, both in their component of power (economic and political pressures to force non-Western countries to accept international intellectual property protection agreements) and in their ideological component, indispensable to reaching agreement (intellectual property justified as a universal natural law conception). Of

85. See Keith Aoki, Neocolonialism, Anticommons Property, and Biopiracy in the (Not-So-Brave) New World Order of International Intellectual Property Protection, 6 IND. J. GLOBAL LEGAL STUD. 11 (1998).

86. For a critique, see UGo MATTEI, COMPARATIVE LAW AND ECONOMICS (1997). The hegemonic consequence of this intellectual cast is stressed by Okediji, supra note 81, at 147-51 (particularly in recent years, the pervasive ideology of liberalized or free trade cast intellectual property protection as a primary factor in penetrating foreign markets and (re)establishing U.S. dominance in the global economy).

87. See Woods, supra note 83, at 389. See generally Lawrence Lessig, The Architecture of Innovation, 51 DUKE L.J. 1783 (2002).

88. See generally MICHAEL BLAKENEY, TRADE RELATED ASPECTS OF INTELLECTUAL PROPERTY RIGHTS: A CONCISE GUIDE TO THE TRIPS AGREEMENTS (1996).

89. For example, the territorial notions of statehood and sovereignty in Kuwait, such as those proclaimed and defended for the last time during the Persian Gulf War (and those that have been forgotten by NATO during the Bosnia strikes), are certainly weakened by the universalistic, non-territorial philosophy that justifies intellectual property as a prize for technological creativity. Why should territorial Gulf and African States own the oil that happens to be within their territorial borders? Why should oil worldwide not be allocated as a prize for the skills in extracting and using it as a source of energy? State territorial sovereignty should yield to the global needs of humankind as interpreted by the global economy. 
course, as in all institutions of hegemony, intellectual property is also onesided, not only in its content but also in its actual use. Suffice it to compare the generic anti-AIDS drugs saga in South Africa (where as many people die of AIDS every week as the victims of the September 11 th events) with the treatment and the respect that the intellectual property of the German-based Bayer pharmaceutical company has been granted by the Bush administration in the aftermath of the Anthrax crisis in the fall of 2001..$^{90}$

In shifting from hegemony to counter-hegemony, one finds more interesting lessons. It is indeed by the use of the internet that the counter-hegemonic potential of the challenge to intellectual property becomes apparent. Gui Debord and the Situationist Internationale movement deserve to be credited with yet another tremendous power of prediction. The author of The Society of the Spectacle and Situationist Internationale have carried on a major attack on the legitimacy of intellectual property rights, based on notions of creativity as leisure and self-fulfillment. Debord has constructed intellectual property as the very fundamental economic and political institution of the spectacle: "The language of the spectacle is made of the signs of the dominating production. Such signs are at the same time the ultimate aim of such production." "As indispensable decoration of the objects that are actually produced, as general claim of the rationality of the system, as leading economic sector that directly produces an increasing variety of objects-images, the spectacle is the main production of present society." In Debord's theory the "spectacle has created a monopoly on what appears." ${ }^{.93}$ By annulling historical knowledge and developing explanations based on structuralism as a sort of science of the necessity, it has incorporated in itself even the most radical critique. ${ }^{94}$ Critique becomes establishment, false becomes true. Critical thinking, in order to wake society up from the passive state in which the spectacle keeps it, has only one way to act-subvert the domain of the original and of the copy: "in the world really subverted the truth is a moment of the false."

90. Notice that the major South African defeat of imperialistic notions of intellectual property in South Africa happened within a "group oriented" cultural model, in which individualistic ideology is less capable of persuasion. See Kevin D. Brown, Globalization and Cultural Conflict in Developing Countries: The South African Example, 7 IND. J. GlobAL LEGAL STUD. 225, 252 (1999).

91. See DEBORD, supra note 39 , at 55 .

92. Id. at 57.

93. Id. at 56.

94. Id. at 172.

95. Id. at 55 . 
Such liberating, subversive theory has to be accompanied by a variety of practices. In the domain of culture and intellectual creativity, the main revolutionary practice is called detournement. The essence of such practice is the denial and radical refutation of any form of intellectual property: "Ideas improve. The sense of words participated in such improvement. Plagiarism is necessary. Progress requires it. Plagiarism siezes the phrase of an author, uses its expressions, cancels a false idea, substitutes it with a true one . . . detournement is the opposite of the citation, of the theoretical authority which is always falsified for the very fact of having been cited. ..."96

As early as 1967, anticipating and radicalizing many of the post-modernist themes such as hybridization and utilization out of the context of the legacy of the past, ${ }^{97}$ Gui Debord had developed a theoretical and political challenge of intellectual property as a political institution of the global society. Debord's critique of the political functions of intellectual property law precedes most of the counter-hegemonic themes of the so-called "copyleft" movement by more than thirty years.

The idea of "copyleft," like Debord's detournemet, plays with words. Left is opposed to right as a political signal, ${ }^{98}$ but left also means abandoned, dropped, given - conveying the sense of free relinquishment and spread of ideas as opposed to copyrighted materials severely and fiercely defended as a property right by the institutions of the global society. The copyleft movement can certainly be perceived as a counter-hegemonic trend, made possible by those very same technological innovations (mainly the internet) that function as a powerful hegemonic force behind Western (and particularly U.S., as the United States alone owns fifty-one percent of world's patents) capitalism. The idea of "open source" dates back to 1984 when the M.I.T. informatics scholar Richard Stallman created the "Free Software Foundation" in order to facilitate free access to the code sources that keep the secrets behind the functioning of software. Many of the political and social concerns of copyleft were already

96. Id. at 74 .

97. Deleuze and Guattari play extensively with notions of in context and out of context. See generally GILlES DEleUZE \& FÉlix GUATTAR, ANTI-OEdIPUS: CAPITALISM \& SCHIZOPHRENIA (Robert Hurley et al. trans., Univ. of Minn. Press 1983) (1972) (offering classic discussions in different contexts) [hereinafter ANTI-OEdIPUS]; GILlES DELEUZE \& FÉLIX GUATTARI, MILlE PlaTEAUX: CAPITALISMÉ ET SCHIZOPHRENIE (1980); see also DAVID HARVEY, THE CONDITION OF POSTMODERNITY: AN ENQUIRY INTO THE ORIGNS OF Cultural Change (1989).

98. This concept of "play" is an unmistakably deconstructive gesture. See generally JACQUES DERRIDA, WRITING AND DIFFERENCE (Alan Bass trans., Univ. of Chicago Press 1978) (1972); JACQUES DERRIDA, MARGINS OF PhILOSOPHY (Alan Bass trans., Univ. of Chicago Press 1972). 
being discussed as early as 1975 within the mythical Silicon Valley "Homebrew Club," a group of socially concerned young scholars that at the dawn of the computer era were already worried about the fate of technological innovation in the hands of the big corporate business. Nevertheless, it was only in the early 1990s that the Finnish student Linus Thovalds launched Linux, the most successful and threatening concurrent of Windows, freely available on the Internet and used today by some eighteen million computers in the world. Linux, constantly and openly improved by its users, who reciprocate free use with suggestions for improvement and problem solving, is based on a clearly anti-copyright philosophy and can be seen as a living demonstration of the ideological nature of pro-copyright rhetoric of innovation. ${ }^{99}$

Other major examples of the counter-hegemonic use of the internet can be found in programs such as Napster which, although eventually enjoined by U.S. courts of law, has developed within the teenage community (and among many artists fed up with being exploited by mega-producers) the idea that music is and should be freely available on the internet. Open Cola has recently provided an example of an "open" product that is that can be copied and improved, in clear antagonism with the highly secretive practice of Coca-Cola and PepsiCola corporations. In the domain of culture and knowledge, Wikipedia, an open internet encyclopedia, allows anybody to improve and add entries, now displaying some 20,000 entries and constantly growing. Finally and most recently is the "open brief" philosophy behind Professor Lawrence Lessig's attempt to challenge the excessive duration of copyrights (between fifty and seventy years after the author's death) in a suit on behalf of the online publisher Eldritch Press. ${ }^{100}$ Professor Lessig is using the legal creativity of U.S. law students from major universities in order to frame the best possible arguments against the excessive duration of copyright law.

\section{HEGEMONY AND COUNTER-HEGEMONY IN LEGAL SCHOLARSHIP}

American legal hegemony can be much better seen (and is much more important) as a change in legal consciousness than as a pattern of

99. See generally LINUS TORVALDS \& DAVID DIAMOND, JUST FOR FUN: THE STORY OF AN ACCIDENTAL REVOLUTIONARY (200I) (explaining the history of the development of Linux and open source platforms); see also generally GLYN MOODY, REBEL CODE: THE INSIDE STORY OF LINUX AND THE OPEN SOURCE REVOLUTION (2001).

100. See Eldred v. Reno, 239 F.3d 372 (D.C. Cir. 2001), cert. granted sub nom. Eldred v. Ashcroft, 534 U.S. 1126,122 S. Ct. 1062 (2002). 
transplantation of legal rules. Legal reception is a highly creative activity, ${ }^{101}$ and legal transplants would be severely misunderstood in their nature if they were approached only as a mechanical import-export exercise. ${ }^{102}$ Much more important is to monitor the diffusion of professional ways of thinking about the law and to address such major intellectual changes as results of the ideological apparatuses of global governance. ${ }^{103}$

It is important to discuss examples of Americanization (and of counterhegemony) at a deep fundamental level of the legal system. By following patterns of changes between sources of law in the last two decades, we should be able to see whether and to what extent legal globalization can be seen as a pattern of legal Americanization. We should be able to conclude that American law in "contexts of reception" is so different from American law in the "context of production" 104 that a universal notion of "imperial law" is necessary to capture the present situation of law in the global context. Notions of legal globalization territorially connected with specific, state-based "contexts of production" (e.g. French Law, German Law, U.S. law) are less useful in perceiving the nature of the post-Cold War legal order. They are too much connected with territorial approaches to comparative law that are now in the process of being reconsidered as a consequence of the powerful birth of institutions of legal globalization (such as the WTO, IMF, EU, and so forth). ${ }^{105}$ Legal systems do not agree on what the formal sources of the law are. For comparative purposes, nevertheless, this disagreement is just another area of comparison, while an agreement has been reached that the relevant sources of law for comparative purposes are not necessarily formal sources of law within the technical meaning of a specific legal system. ${ }^{106}$ I will explore the present phase of globalization/Americanization in three fundamental places: legal

101. See GRANDE, supra note 8; see also Pier Giuseppe Monateri \& F.A. Chiaves, Shifting Frames: Law and Legal "Contaminations," in INTRODUCTION TO ITALIAN LAw 21 (Jeffrey Lena \& Ugo Mattei eds., 2002).

102. Considering the law as a mechanical commodity that can be imported or exported like a television set or a Land Rover is also a strategy of governance. See Ugo Mattei, Legal Transplants, Legal Pluralism and Economic Development, in NEW LAWS FOR NEW STATES (L. Favali et al. eds., 1999); see also LAURA NADER, THE LifE OF THE LAW: ANTHROPOLOGICAL PROJeCTS (2002).

103. See generally Mathias Reimann, Droit positif et culture juridique: L'américanisation du droit européen par réception, 45 ARCHIVES DE PHILOSOPHIE DU DROIT 61 (2001) (discussing Americanization as a change of mentality).

104. This important notion is introduced by Medina, supra note 3.

105. See, e.g., Mathias Reimann, Towards a European Civil Code: Why Continental Jurists Should Consult Their Transatlantic Colleagues, 73 TUL. L. REV. 1337 (1999); see also MARIA ROSARIA FERRARESE, LE ISTITUZIONI DELLA GLOBALIZZAZIONE: DIRITTO E DIRITTI NELLA SOCIETẢ TRANSNAZIONALE (2001) (discussing the legal institutions of globalization).

106. See generally Sacco, supra note 23. 
scholarship, case law, and codification. If I succeed in offering evidence of a deep and pervasive impact on intimate and traditionally local aspects of the law, the idea of "imperial law" as the outcome of such processes should become even more persuasive.

This section focuses mainly on the impact of Law and Economics, a highly influential approach to law in the contemporary process of making European private law, as well as one of the most influential scholarly approaches within the World Bank and the International Monetary Fund. ${ }^{107}$ The reader should keep in mind that when a new paradigm of legal scholarship is able to seize a leading position, it is usually by making previous approaches look obsolete and primitive. An example is the French exegetic methodology, which was considered obsolete by the much more elegant and scientific German-Pandectist approach. The Franco-German-inspired social approach, advertised as a step forward in civilization compared to the previous "Lochner-Era" individualism, may have also become the leading position in this way. This is certainly the case in present U.S. hegemony, offering an expansive universalistic global model that expresses itself in English (the new lingua franca), that keeps a dialogue open with economics (the queen of social sciences), and that claims to be the new natural legal order of the post-Westphalian state society based on imperial law. Such a legal system, short of being politically legitimized, receives its legitimacy and desirability by the intrinsic virtues of general access to the global capitalist market place, a dream spelled out at the front door of the luxurious building of the World Bank in D.C.: "We Dream of a World Free from Poverty."

Imperial law, as short of being a mode of governance in need of legitimacy as any other, becomes the technological backbone of the global marketsomething to be approached apolitically, to be described and modified only by technological practices. For the first time after the Cold War, funding is available for scholars who wish to be the technocrats and the engineers of this apolitical system. Within these assumptions, any approach to the law that still considers it as a political institution that cannot be understood and described in graphs and numbers is disposed of as obsolete, and any approach that requires something other than a reactive minimal philosophy of governance is entirely out of fashion after the fall of the Berlin Wall. Law has to create incentives for

107. Cf. generally M. W. HESSELINK, THE NEW EUROPEAN LEGAL CULTURE (2001) (discussing changes in current private law thinking in Europe). See also Reimann, supra note 103 (indicating a more nuanced position). 
market actors. The skilled lawyer and policymaker is not appreciated if his suggestions require a proactive and expensive activist posture of governments, let alone if he argues for economic redistribution by taxation or other obsolete Keynesian measures. The legal scholar can count only on the natural existence of markets: his role is to produce a correct set of market incentives. The quintessential example of this attitude is the celebrated "self-sufficient" model of corporate reform produced by leading Columbia University scholar Bernard Black (now at Stanford Law School) for the Russian Federation. ${ }^{108}$

The institutional background of U.S. law was the highly original context in which the legal process, the first genuinely original paradigm of American legal scholarship, developed its analysis. ${ }^{109}$ The United States is the only generally federalized judicial system in the world. U.S. law, therefore, has to cope with a number of unique potential conflicts between institutional actors, something that naturally makes lawyers develop a tremendously sophisticated consciousness on the practical importance, in litigation, of who decides what. ${ }^{110}$ Within U.S. legal culture, the unprecedented degree of anti-formalist hegemony experienced by American legal realism called for some reaction. In Germany and France, the two leading exponents of the civil law tradition, antiformalism has never successfully reached beyond the status of a critical current of legal thought, only marginally influential outside of legal scholarship. ${ }^{111}$ On the contrary, in the United States, legal realism was able to seize the leading posture among legal approaches in academia and also, not marginally, in the judiciary and the administrative state. ${ }^{112}$

The reaction to legal realism, produced by the legal process school mainly in public law and by the economic analysis of law in private law, had no foreign models by which to be inspired. If seen in the domestic perspective of

108. See generally Bernard Black \& Reinier Kraakman, A Self Enforcing Model of Corporate Law, 109 HARV. L. REV. 1911 (1996).

109. See generally HENRY M. HART \& ALBERT M. SACKS, THE LEGAL ProCESS (1994) (reviving attention to the legal process school of thought); see also generally NEIL K. KOMESAR, IMPERFECT ALTERNATIVES: CHOOSING INSTITUTIONS IN LAW, ECONOMICS, AND PUBLIC POLICY (1994) (discussing the merger of legal process theory and law and economics). Predating the legal process school, the roots of both legal formalism and legal realism can be traced to Europe. See Kennedy, supra note 34.

110. See generally RICHARD H. FALLON ET AL., THE FEDERAL COURTS AND THE FEDERAL SYSTEM (4th ed. 1996) (discussing the other "classic" of the legal process school); see also generally Akhil Reed Amar, Law Story, 102 HARV. L. REV. 688 (1989) (reviewing RICHARD H. FALLON ET AL., THE FEDERAL COURTS AND THE FEDERAL SYSTEM (3rd ed. 1988)).

111. See Carlo Augusto Cannata \& Antonio Gambaro, 2 LINEAMENTI DI STORIA DELLA GIURISPRUDENZA Europea: Dal Medioevo all'EPOCA CONTEMPORANEa (4th ed. 1989).

112. See generally GRANT GiLmORE, THE Ages OF AMERICAN LAW (1977); BRUCE A. ACKerman, RECONSTRUCTING AMERICAN LAW 105-10 (1984) (appraising the realist hegemony in U.S. law). 
U.S. law, both the legal process and the economic analysis of law share an ambiguous relationship with formalism and realism. It would be difficult to imagine the birth of the legal process outside of the very peculiar U.S. federal system, while, because of the nature of economic reasoning, the economic analysis of law is a universalistic paradigm. As a consequence of this different degree of local specificity, only law and economics has been able to become a world-wide hegemonic form of legal consciousness.

While it would a gross exaggeration to claim that law and economics today enjoys the leading role as an approach to legal scholarship in European countries, we can nevertheless see that it is the main intellectual vehicle used by American legal consciousness to diffuse itself and to impose its hegemony in the center and periphery of the world. ${ }^{113}$ The notoriously expansionistic and universalistic blend of neoclassical economic analysis, together with the very thick layer of ideological assumptions that are imbedded in economic reasoning and that produce the development of the evolution towards economic efficiency as a sort of second nature, are all behind the intellectual success of this line of reasoning about the law. ${ }^{114} \mathrm{~A}$ very clear bias in favor of the efficiency of the common law adjudication process promotes the reactive posture of the courts of law as the normative philosophy of U.S. academic discourse. Privatizations and structural reforms, sustained by the international institutions of global governance, make law and economics one of the most important cultural currents that diffuse tacit assumptions of U.S.-based imperial legal consciousness.

Law and economics, once transplanted outside of its context of production, displays the high level of ambiguity that allows it to flourish. Conservative scholars admire its intellectual elegance; more progressive and liberal scholars see its potential in subverting the highly formalistic and black letter flavor of local law, and claim that the conservative political bias is something that can be left on the other side of the ocean. ${ }^{115}$ Many European scholars are attracted to law and economics, and even when attempting to use it critically, are paving the

113. Ugo Mattei \& Alberto Monti, Comparative Law and Economics: Borrowing and Resistance, in 1 GLOBAL JURIST FRONTIERS (2001), at www.bepress.com/gj/frontiers/voll/iss2/art5/.

114. See generally Duncan Kennedy, Law and Economics from the Perspective of Critical Legal Studies, in THE NEW PALGRAVE, supra note 1 , at 465.

115. See generally F. Pulitini, Appunti sull' analisi economica del diritto, I MERCATO CONCORRENZA E REGOLE (forthcoming 2003) (critical appraisal by an early Italian scholar of law and economics of the opportunity to consider Chicago and other brands of Law and Economics as movements sharing enough communalities to be approached within a unitary taxonomic scheme). 
way to scholarly Americanization and becoming part of the very same world phenomenon of hegemonic imposition that they would like to criticize.

The distinctive American flavor of law and economics leaves open a fundamental question: what is the legitimacy of a scholarly paradigm when applied outside of the cultural context in which it has been developed? What are the political implications of using law and economics outside of the cultural environment in which it has developed? Is a new legitimacy necessary for the context of reception, or is the one captured in its original environment also sufficient for the new one? It is urgent that such critical questions are approached within a broad historical context, in which present trends are not taken for granted and in which local specificities are fully appreciated in their political meaning. Such a critical exercise is even more needed if law and economics aims at establishing itself, as discussed in the previous sections, as one of the fundamental methodologies of the new imperial legal order.

Recent scholarship ${ }^{116}$ has pointed out that law and economics has entered a post-modern, interpretive phase of development in which its nature of a grand discourse over the nature of law aiming at objectivity has yielded to a local micro-strategy grounded in pragmatism. Using such strategy, legal scholarship pursues hegemony and influence over the other sources of U.S. law by means of a radically neo-pragmatist attitude. Such critical development has been fostered by a general loss of faith in the objectivity of efficiency-based discourses, the very same faith that in previous times had guaranteed to law and economics, and to economics in general, their hegemony within the post-realist approach to legal scholarship and within other social sciences. ${ }^{117}$ Such evolution can be seen in all its fundamental importance from the perspective of legitimacy of the legal discourse, if one takes into consideration that the quest for objectivity had already been at the roots of the legal process school in the fifties. ${ }^{118}$ In the United States today, law and economics has been finally unseated from the throne of legal objectivity, so that its normative recipes need a new contingent and local legitimization in order to compete with those of a variety of opposite political strategies.

116. See generally GARY MINDA, POSTMODERN LEGAL MOVEMENTS: LAW AND JURISPRUdENCE AT CENTURY'S END (1995); see also generally STEPHEN M. FELDMAN, AMERICAN LEGAL THOUGHT FROM PREMODERNISM TO POSTMODERNISM: AN INTELLECTUAL VOYAGE (2000); NICHOLAS MERCURO \& STEVEN G. MEDEMA, ECONOMICS AND THE LAW: FROM POSNER TO POST-MODERNISM (1997).

117. See generally Robert D. Cooter, Law and the Imperialism of Economics: An Introduction to the Economic Analysis of Law and a Review of the Major Books, 29 UCLA L. REV. 1260 (1982).

118. See generally Herbert Wechsler, Toward Neutral Principles of Constitutional Law, 73 HARV. L. REV. $l$ (1959) (advocating judicial review after careful evaluation of other possible solutions to the issue at hand). 
The traditional grand theory of law and economics has been successfully received and implemented by the new all-powerful producers of global law, the private and public international institutions of global governance (the WTO, World Bank, IMF, mega-law firms, and so forth). In this institutional scenario, successfully described recently as Empire ${ }^{119}$ or as Polyarchy promotion, ${ }^{120}$ even lively scholarly debates happening only in one place (however hegemonic such as the United States) cannot help but be parochial and ineffective, particularly as far as the voices of intellectual resistance and critique are concerned. The emerged false opposition - between a global dimension, which is the domain of the market and of efficient institutions, and a local dimension as the location of solidarity and politics - requires a genuinely cosmopolitan legal culture to be exposed and challenged.

As pointed out in a recent essay, traditional comparative law is particularly ill-equipped to tackle the critical analysis necessary in order to study and understand the "new" legal systems of the global world, those non-territorial suppliers of law that characterize the present landscape (WTO, IMF, and so forth). ${ }^{121}$ Indeed, traditional comparative law is prisoner of a territorial national paradigm of inquiry that is all but dead as a tool for understanding legal globalization. Thus, in order for the comparativist to become an effective global lawyer, it is necessary to rethink radically the modern idea of borders. Tools must be invented to compare non-territorial legal systems between themselves as well as with territorial ones.

The a-critical reception of law and economics, with its grand discursive strategy based on efficiency and objectivity, then becomes the ideological apparatus of global authority. Alternatively, when eventually (if at any point) the post-modern vein of U.S. law and economics becomes understood, the reception will remain embedded in postmodernism, "the logic by which global capital operates." 122

In the United States, despite a number of contradictory characters, postmodernist legal paradigms have been able to "develop as a radical critique of both formalist and realist paradigms competing with each other for cultural hegemony in the legal academy ... [by challenging] the American dream, the

119. See HARDT \& NEGR, supra note 10, at xi-xii (defining Empire as the political subject that regulates global markets and global circuits of production).

120. See ROBINSON, supra note 9.

121. See generally Mathias Reimann, Beyond National Systems: A Comparative Law for the International Age, 75 TUL. L. REV. 1103 (2001).

122. HARDT \& NEGRI, supra note 10, at 151. 
realist market pragmatism, and the simplifying assumptions of the leading paradigms of research." 23 Even setting aside here the devastating impact of economic modernization, carried on by means of western conceptions of the law in societies that have followed different paths of development, ${ }^{124}$ it is clear that outside of the American cultural and institutional context, legal phenomena are quite different. For example, in the European legal landscape, still possessed by the self-serving formalist and localized attitude of the legal discourse, there is a need to introduce some values of modernity rather than to entertain postmodernist critique. A number of pre-modern aspects of European society still strike the observer. For example, formalism, a value symbolizing class division, has never been replaced by informality and openness. Hence in Europe, postmodernism reinforces the pre-modern status quo, even at a superficial level of analysis. From a cultural perspective, it legitimizes the forces opposing radical institutional remodeling of legislatures, courts, and scholarship such as those needed in order to counterbalance American legal hegemony.

Interestingly, the influence of American scholarly thought in the law, as applied to such a highly political exercise as the building of the new European legal landscape, shows even more division and more need to distinguish differences of attitude in the process of reception. A wide gap between northern and Latin European countries in attitude towards the reception of American-inspired modes of thought about the law is too apparent to be neglected. Northern countries, including Germany, Holland, Great Britain, and the Scandinavian countries, have incorporated much of the new American attitude towards the legal discourse as symbolized by law and economics. In such countries, the internalization of leading U.S. modes of thought in the law, such as balancing jurisprudence (including law and economics), has tremendously increased in the last ten years. The "new European legal culture," mostly made by scholars belonging to such northern countries where the university system does not live in a state of disarray, and in which law professors are mostly full time scholars or (some of them) policymakers, is

\footnotetext{
123. Ugo Mattei \& Anna di Robilant, The Art and Science of Critical Scholarship: Postmodernism and International Style in the Legal Architecture of Europe, 75 TUL. L. REV. 1053, 1085-86 (2001).

124. See generally JAMES A. GARDNER, LEGAL IMPERIALISM: AMERICAN LAWYERS AND FOREIGN AID IN LATIN AMERICA (1980) (analyzing and critiquing American legal assistance in the developing world with special emphasis on Latin America); see also generally David M. Trubek \& Marc Galanter, Scholars in SelfEstrangement: Some Reflections on the Crisis in Law and Development Studies in the United States, 1974 WIS. L. REV. 1062 (1975) (examining the relationship between the legal system and the social, economic, and political changes occurring in Third World countries).
} 
much more similar to U.S. legal culture than to the traditional European one. ${ }^{125}$ This new European legal culture, dominated by northern scholars able to express themselves in English, is the most influential in European private law drafting. The outcome of such northern reception is a technological attitude towards the legal discourse, traditionally foreign to the European style and very functional to the legitimizing strategy of non-politically accountable technobureaucratic elites within the European Commission.

Nevertheless, legal Europe is not made only by northern, Anglophone elites. A variety of resisting attitudes can be shown too, particularly in southern Latin countries resenting their marginalized status in the exercise of building European law. Such Latin counter-cultures are occasionally originated simply by the cultural incapacity to participate in policy-oriented discussions about the law, because leading lawyers in those countries are still the product of a highly formalistic interpretive culture. Sometimes, such resisting attitudes are due to the still notable strength of the "social mode of thought about the law" which leads to the belief that the neo-American model carries with it reactionary eighteenth-century models of capitalism. ${ }^{126}$ Indeed the early resistance against law and economics in Europe was politically motivated by that same belief, even in Northern European countries. ${ }^{127}$ A third mode of resistance with clear ambitions of counter-hegemony is unfolding within the critical comparative law community by the use of historiography, anthropology, and neo-institutional economics. Such an emerging comparative community, ${ }^{128}$ directly connected with U.S. critical scholars ${ }^{129}$ and with European critical philosophy, ${ }^{130}$ is carrying on a genuine attempt to exploit the "subversive function" of comparative law in order to take advantage of the much more cosmopolitan

125. See HESSELINK, supra note 107; see also text accompanying notes 107-15.

126. See Anna di Robilant, Globalization of the Social? An Italian Counter-Fire, 11 EUR. REV. PRIVATE L. (forthcoming) (noting the importance of the "social achievements" of the European legal tradition such as the "social function" of property rights that has been abandoned in the socially inspired European Charter of Rights). See generally ANDREA MANZELLA, RISCRIVERE I DIRITTI IN EUROPA: LA CARTA DEI DIRITTI FONDAMENTALI DELL'UNIONE EUROPEA (2001).

127. For an account of the early reception of law and economics in Europe, see Robert Cooter \& J. Gordley, Economic Analysis in Civil Law Countries: Past, Present, Future, 11 INT'L REV L. \& ECON 261 (1991). 128. Among the important contributions, see Horatia Muir Watt, La Fonction Subversive du Droit Comparé, 52 REVUe INTERNATIONALE DE DROIT COMPARE 503 (2000); HESSELINK, supra note 107; P.G. Monateri, Black Gaius: A Quest for the Multicultural Origins of the "Western Legal Tradition", 51 HASTINGS L.J. 479 (2000); Mauro Bussani, Choix et Défis de L'herméneutique Juridique Notes Minimes, 50 REVUE INTERNATIONALE DE DROIT COMPARE 735 (1998); GRANDE, supra note 8.

129. See Symposyum: Critical Legal Studies in Europe, 9 EUR REV. PRIVATE L. (2001); Elisabetta Grande, Introduction to LAURA NADER, LE FORZE VIVE DEL DIRITTO (2002).

130. See DiRITTO, GIUSTIZIA E INTERPRETAZIONE (Jacques Derrida \& Gianni Vattimo eds., 1998). 
flavor of minority European legal cultures, which have been forced by political necessity to look beyond localism and to develop worldly approaches to the legal discourse. ${ }^{131}$ Such approaches are particularly interested in opening a channel of exchange with the traditional periphery, with particular sensitivity to the issues of Islam, boundaries, and exclusion.

\section{COURTS AS AGENCIES OF U.S. HEGEMONY}

As discussed above, U.S. law has been able to receive and to "exaggerate" from Germany and from England, the two main agencies of professional check over the political process: legal scholarship and the judiciary. Both of these agencies, entrusted with considerable political power, have no purse, are inspired by a reactive philosophy, and are ill-equipped for any proactive redistributive role. A universalistic notion of rights, received from the French naturalistic tradition, has also been exaggerated in the United States. This section explores the hegemonic consequences of a universal discourse on rights enforced by a strong system of courts. ${ }^{132}$ It further dwells on the global consequences of the reactive philosophy in contexts in which courts do not operate as effectively as the American ones in the enforcement of rights.

While the development of a leading legal scholarship in the United States is a relatively recent accomplishment, ${ }^{133}$ the development of an all-powerful judiciary in charge of many policy decisions was noticed quite early by Alexis de Tocqueville. ${ }^{134}$ Naturally, scholars are those who provide consent to

131. The idea of a subversive function of comparative law has been advanced by George Fletcher. See generally George P. Fletcher, Comparative Law as a Subversive Discipline, 46 AM. J. COMP. LAW 683 (1998). This approach attempts to create a potential "new-global" way of thinking about the law stemming from a Latin (or more generally Mediterranean) resistance to the status quo and incrementally transforming it into an effective counter-hegemonic force. Whether this is a reality or only the projection of the present author is an open question. Nevertheless, some common patterns of analysis are emerging and they certainly include the relentless critique of universalizing human rights approaches, the constant attention to minority jurisdictions, the de-legitimization of the leading Euro-American focus of comparative legal and political analysis, the issue of linguistic diversity, the struggle against arrogance and chauvinism in legal scholarship, and the constant effort to expose hidden assumptions able to create "a second nature" and capable of hiding political choices behind technocratic skills. Similarly, a call for subversive practice is a dominant theme in continental philosophy. See generally MARTIN HEIDEGGER, BASIC WRITINGS: FROM BEING AND TIME(1927 TO THE TASK OF THINKING) (David Farrell Krell ed., 1977) (1964).

132. See generally THE Global EXPANSION OF JudicIal POWER (C. Neal Tate \& Torbjöm Vallinder eds., 1995).

133. The date of birth of the American inspired legal globalization is after World War II's aftermath. See Mattei, Why the Wind Changed, supra note 24; Kennedy, supra note 34

134. See DE TOCQUEVILLE, supra note 27. 
scholarly hegemony. When we shift our attention to U.S. courts as agencies of hegemony, we are faced with the problem of detecting the agents of agreement to such a hegemonic role. My claim here is that the plaintiffs' bar is playing such a role and that, again, the last decade has shown significant changes. In other words, while courts of law have been a strong and very influential institutional branch throughout U.S. legal history, it is only in this last decade that they have started to perform a major global hegemonic role.

The story of courts of law as hegemonic agencies of the global legal order began unfolding in post-World War II developments, and reached its final stage in post-Cold War jurisprudence. The Holocaust played a direct role in both of these phases. ${ }^{135}$ In the immediate aftermath of World War II, the Nuremberg trial planted the seeds of an idea of international legality based on special courts of law, with a mode of faith in the judiciary. While the notion of courts capable of enforcing universal human rights is certainly rooted in the Nuremberg trial, ${ }^{136}$ the idea that the national system of U.S. courts of law can provide this role worldwide is a post-Cold War development, with the U.S. Holocaustrelated litigation as its central drama. ${ }^{137}$

As is well known, numerous lawsuits have been filed in U.S. federal and state courts asserting what are now commonly referred to as "Holocaust claims." In these claims for events arising out of World War II, plaintiffs maintain that the wrongs alleged-which include concealed bank accounts, looted assets, looted art, and insurance policy claims-are best adjudicated by U.S. courts because various procedural mechanisms of the U.S. judicial system allow efficient disposition of the claims. Each case involves stories about stillliving plaintiffs, or their friends and family, being either brutally subjected to Nazi horror during the war (looted asset and slave labor claims), or unscrupulously denied access to their legal entitlements after the war (insurance and bank deposit claims). Commissions have been authorized and funded in Switzerland, France, and the United States ${ }^{138}$ to pursue the question. ${ }^{139}$

135. See Kennedy, supra note 34.

136. See generally ANTONIO CASSESE, VIOLENCE AND LaW IN THE MODERN AGe (1988). See also generally David Held, International Law, in THE GLOBAL TRANSFORMATIONS READER, supra note 42, at 167.

137. The following section is based on my previous work with Jeffrey Lena. See Ugo Mattei \& Jeffrey S. Lena, United States Jurisdiction over Conflicts Arising Outside of the United States: Some Hegemonic Implications, 1 GLOBAL JURIST TOPICS (2001), at http://www.bepress.com/g/topics/vol 1/iss2/art5/.

138. Two studies under the direction of Stuart Eizenstat focused public attention on the issue and added political pressure to reach settlements in many of the cases brought. STUART EIZENSTAT \& WILLIAM Z. SLANY, U.S. AND ALLIED EFFORTS TO RECOVER AND RESTORE GOLD AND OTHER ASSETS STOLEN OR 
Substantial and factually non-frivolous claims have also been filed in U.S. courts by both U.S. and foreign nationals for forced labor and sexual slavery imposed by the Japanese in the Pacific Theatre of the war.

The U.S. Constitution, drafted in 1787, reflects the natural law beliefs that dominated eighteenth-century jurisprudence. A primary tenet of that belief was the recognition, preservation, and vindication of individual rights, whether they arose in the United States or abroad. The framers and the first generation to follow them gave substance to that belief, in part through the idea that international law could be seen as a system of customary protection of such rights. This principle was reflected in Article III of the Constitution itself, which, while concerned with limiting federal jurisdiction vis-à-vis the state courts of the United States, broadly interpreted the notion of cases "arising under the Constitution ... [and] . . the Laws of the United States" to include international law claims based not only upon treaties, but upon custom as well. The U.S. Constitution also granted "alienage" jurisdiction in all cases between "a State, or the Citizens thereof, and foreign States, citizens or Subjects." This set the stage for the expansive vision of federal court authority in all areas that touched on foreign affairs. ${ }^{140}$ Congress further extended subject matter jurisdiction to U.S. federal courts through passage of the Alien Tort Statute, part of the original Judiciary Act of 1789 . While originally more restrictive in scope and practical use, that statute, today codified as 28 U.S.C. $\S 1350$, provides that "The district courts shall have original jurisdiction of any civil action by an alien for a tort only, committed in violation of the law of nations or a treaty of the United States." The origins of the Act remain somewhat obscure and, for almost 200 years, the statute lay practically dormant. But the statute suddenly came to life in the case of Filartiga $v$. Pena-Irala, ${ }^{141}$ in which the

HIDDEN by GermaNy DURING WORLD WAR II: PRELIMINARY STUdy (1997), available at hitp:// www.ess.uwe.ac.uk/documents/asetindx.htm; STUART EIZENSTAT \& WILLIAM Z. SLANY, U.S. AND ALLIED WARTIME AND POSTWAR RELATIONS AND NEgotiations WITH ARgENTINA, PoRTUGAL, SPAN, SwEDEN, AND TURKEY ON LOOTED GOLD AND GERMAN EXTERNAL ASSETS AND U.S. CONCERNS ABOUT THE FATE OF THE WARTIME USTASHA TREASURY (1998).

139. A substantial amount of literature has emerged on the question. See, e.g, RICHARD Z. CHESNOFF, PACK OF THIEVES: HOW HITLER AND EUROPE PLUNDERED THE JEWS AND COMMITTED THE GREATEST THEFT IN HISTORY (1999); MARK AARONS \& JOHN LOFTUS, UNHOLY TRINITY: HOW THE VATICAN'S NAZI NETWORKS BETRAYED WESTERN INTELLIGENCE TO THE SOVIETS (1992).

140. The logic behind the federal courts taking original jurisdiction over these matters was to ensure that the matters would be heard, to the greatest extent possible, in federal as opposed to state courts, on the theory that the federal sovereign, having been vested with sole power over foreign relations, should also have jurisdiction over matters concerning the law of nations. This effectively limited state court jurisdiction, which was in all respects not limited by the federal Constitution.

141. 630 F.2d 876 (2d Cir. 1980) 
court held that the act complained of - torture of a Paraguay citizen by a Paraguay official acting under color of law-violated the "law of nations" that, according to Article III of the Constitution, was directly incorporated into federal common law. ${ }^{142}$ Thus, the embryonic but clear potential for U.S. courts of law to vindicate wrongs committed throughout the world, and thereby protect the natural rights of the world's individuals, was finally given expression. Such jus cogens violations of natural rights conflicting with clearly established norms of international law can and do happen everywhere in the world, in theory transforming the United States into a forum for all the world's grievances. ${ }^{143}$

Such potential world-wide jurisdiction of the American judiciary has been historically balanced by a number of countervailing principles, such as the doctrine of "minimum contacts" and the constitutional doctrine of "justiciability." Other doctrines, such as forum non conveniens, have been elaborated by U.S. courts to safeguard the principle of their jurisdiction while simultaneously refusing to keep jurisdiction when it is more proper to have the litigation unfold outside the United States. While employment of the doctrine is not uniform among state courts, some uniformity has developed on the federal level after the Supreme Court wrote extensively on the topic in Piper Aircraft Co. v. Reyno. ${ }^{144}$ Nevertheless, a forum non conveniens decision by a trial court remains based upon a balancing of interests and the decision remains within the "sound discretion" of the court.

Beginning in 1996, the impressive explosion of Holocaust-related litigation provided world-wide visibility to this phenomenon. ${ }^{145}$ Indeed, European lawyers representing a large number of Europe-based corporations active in the insurance, banking, and industry are today involved in one capacity or another in litigation on both coasts of the United States concerning hundreds of claims based on facts that occurred more than a half century ago. Because of the

142. This, of course was not a new idea. See, e.g., United States v. Smith, 18 U.S. 153, 161 (1820) ("The common law ... recognises and punishes piracy as an offence, not against its own municipal code, but as an offence against the law of nations...."). The development is described in JORDAN J. PAUST, INTERNATIONAL LAW AS LAW OF THE UNITED STATES (1996).

143. One of the reasons that the use of intemational law as a basis for asserting claims under Federal Common Law was slow to develop was that general consensus as to what might be considered a violation of a jus cogens norm only developed in the second half of the Twentieth Century. See Iwanowa v. Ford Motor Co., 67 F. Supp. 2d 424, $439-40$ (D.N.J. 1999) (describing the growing consensus as to what constitutes a violation of a jus cogens norm); see also RESTATEMENT (THIRD) OF FOREIGN RELATIONS LAW §§ 102(2), 702 (1986).

144. 454 U.S. 235 (1981).

145. See Michael J. Bazyler, Nuremberg in America: Litigating the Holocaust in United States Courts, 34 U. RICH. L. REV. 1 (2000) (detailing the various holocaust cases from the plaintiff's perspective). 
distance of the Holocaust from the United States, ${ }^{146}$ and because of the nature of judicial challenge to actions carried on under shadow of foreign law and politics, the holocaust litigation is the most extreme and emblematic episode of a world-wide trend in international litigation in which U.S. courts promote themselves as de facto judges of world history.

In addition to the emotional implications of such litigation, which requires us to relive one of the most horrible tragedies in recorded history, the holocaustrelated litigation seems an indictment of the very activist jurisdictional posture of the U.S. courts. Such posture is now resented as a major phenomenon of legal imperialism because of the way in which it imposes American standards not only of substantive law (which are, with respect to these appalling events, in any case largely shared by most nations in the world), but also of procedure and of legal culture. In particular, the pro-plaintiff (relative to the rest of the world) attitude of United States procedure, which has already created so many problems, ${ }^{147}$ may impose standards that offend the legal sensibilities of nonAmerican lawyers. Interestingly, none of the almost five hundred Holocaust related actions filed in U.S. federal or state courts (with the exception of one important insurance holocaust claim and one French bank claim $)^{148}$ have ever reached the stage of a full-fledged decision on the comprehensive "motion to dismiss." 149

146. From another perspective it may be noted that not uncommonly plaintiffs are persons who were once citizens of some European country and subsequently became U.S. citizens. Like any country's courts, U.S. courts would like to offer a forum to their own citizens. This does not change the fact, however, that the events themselves took place generations ago, on another continent, when the plaintiff was the citizen of another country.

147. For example, the disputes that arose during the Evidence Convention negotiations at the Hague Conference of Private International law. The best and most accessible discussion of this remains SCHLESINGER ET AL., supra note 32, at 470-75.

148. Stern v. Assicurazioni Generali S.p.A., (No. BC 185376) (Califomia State Court insurance claim filed in 1999) (Jurisdiction asserted, after which the case was settled); Bodner v. Banque Paribas, 114 F. Supp. 2d 117 (E.D.N.Y. 2000) (motion to dismiss in bank account case on standing, comity, and statute of limitations grounds denied and case allowed to proceed); Altmann v. Republic of Austria, 142 F. Supp. 2d 1187 (C.D.Cal. 2001) (court denied motion to dismiss on grounds of full sovereign immunity).

149. The "Motion to Dismiss" in United States Federal Procedure occurs at an initial stage of the litigation in which defendants may raise a number of initial defenses including: statute of limitations, failure to state a claim, non-justiciability, comity, lack of standing to sue, lack of subject matter jurisdiction, lack of personal jurisdiction, and others under Federal Rule of Civil Procedure 12 (Rule 12). State Courts, though they do not follow the Federal Rules, have similar procedural mechanisms for challenging plaintiffs' claims. Rule 12 motions can be brought successively as the case develops. So, for example, where a first motion to dismiss for lack of subject matter jurisdiction fails, if additional facts develop indicating that the court does not have subject matter jurisdiction over the claim, that defense may be reasserted. 
Even at the earliest stages, nevertheless, plaintiffs will ask the court to allow them some limited discovery, usually related to jurisdictional matters. ${ }^{150}$ The stunning reach of U.S. discovery ${ }^{151}$ is one of the most important factors explaining the present hegemony of U.S. law in world-wide litigation. American-style discovery, often experienced by defendants as a "fishing expedition," is traditionally very much resented in European countries, as is well-documented by Article 13 of the Hague Evidence Convention, which allows signatory countries to decline to cooperate in matters of American-style discovery. Even the early stage is complicated, time consuming, and very expensive. For example, in a complex international litigation involving issues of foreign law, a rather extensive role of expert witnesses might be involved. Not only do issues of law have to be addressed by expert declarations, but litigants must also address factual questions that might require expensive declarations as well (e.g. by historians, bankers, experts of business practice, and the like, who typically have to be hired and compensated). Moreover, the responsible attorney must absorb, to a great extent, the impact of the foreign law on the case and be prepared to argue it both in the briefs and at oral argument. Since each point of law in the motion to dismiss has to be thoroughly briefed-involving massive searches of the case law for helpful precedent-a large number of attorneys are typically involved in various capacities, who are compensated at rates usually ranging from $\$ 200$ to $\$ 500$ dollars per hour. It is no exaggeration to estimate that that resisting even an entirely spurious claim involving complex international litigation in the United States might cost a defendant not less than one million dollars per year. This "third factor"- -the high cost of litigation-in part explains the high rate of outof-court settlements.

Besides discovery, other difficulties exist, such that suits in U.S. courts put high financial pressure on defendants. To begin with, the system of attorney's compensation is, at least in tort cases, very attractive for plaintiffs. Plaintiffs' attorneys are usually compensated on a contingency basis. Defense attorneys, on the other hand, are typically compensated on an hourly basis, which is typically less lucrative compared to the cases that end in a plaintiff's windfall,

150. Presently the federal "default" discovery rules provide that the parties must exchange relevant meritsrelated documents at the outset of the proceedings; where jurisdictional defenses are raised, however, defendants may seek relief from such initial document exchange.

151. FED. R. CIV. P. 26. 
but which constitutes a more certain form of compensation. ${ }^{152}$ For the plaintiff, suing in a U.S. court is a "risk free, no cash advance" enterprise. This would be impossible in any other jurisdiction, due to restrictions in the availability of contingency fee agreements. Tort law in the United States has been very creative in terms of doctrines employed to extend liability to defendants. One need only think of the "market share liability" concept first employed in the pharmaceutical class action setting. ${ }^{153}$

A second feature of the system is, of course, the availability of punitive damages. A third is the employment of the jury to determine liability and damages. Jurors tend to be sympathetic with victims, adopting a "rough equity" approach, and are sometimes quite liberal with standards of proof. ${ }^{154}$ Finally, and perhaps most obviously, the vehicle of the class action, which allows "representative" plaintiffs to pursue the action on behalf of a "plaintiff class," is one of the most powerful attractions of a U.S. forum. Sometimes litigation in the United States is the only vehicle available for vindication of these kinds of rights. And this is indeed one of the strongest rhetorical reasons for the hegemony of American law in the international context. The class action is a technical device that allows relatively small individual interests that could never afford the costs of litigation to aggregate, forming a large and structured interest strong enough to attract plaintiff's lawyers to litigate the claims. Invariably, the winning strategy for plaintiffs opposing forum non conveniens motions is to show that the interest that is litigated as a class action in the United States could never find access to courts anywhere else in the world because of the lack of the class action as a tool. ${ }^{155}$

152. In the so-called "faimess hearings" under FED. R. CIV. P. 23(e), courts are required to determine whether the compensation of class action attorneys is a fair and reasonable sum. While the typical contingent fee is thirty percent before trial and forty percent after trial, compensation to attomeys in the holocaust litigation has hovered between one and three percent. Such compensation has been approved as "fair" as far as we can determine. There is no question, on the other hand, that the exposure engendered by these cases is surely beneficial to acquiring future business.

153. See Linda S. MulleniX, MASs TORT Litigation 671-711 (1996).

154. See, for a pro-defendant perspective, STEPHEN SUGARMAN, DONG AWAY WITH PERSONAL INJURY LAW (1989); PeTERW. Huber, LIABILITY: THE LEGAL REVOlution AND ITS CONSEQUENCES (1988). Overgenerosity of the jury in favor of plaintiffs is one of the main indictments of the present tort system. See generally LAURA NADER, THE LIFE OF THE LAW: ANTHROPOLOGICAL PROJECTS (2002). Throughout this book but particularly in the last chapter, "The Plaintiff: A User Theory,"Nader fundamentally challenges the soundness of these critiques and points at their ideological nature.

155. The idea that only courts can vindicate rights is based on an idea that naturalizes the American institutional (reactive) setting. The argument works on the assumption that proactive institutions such as administrative agencies and other apparatuses, grounded in thick conceptions of the State, simply cannot effectively protect holocaust victims, the environment, or monitor the pharmaceutical business. But indeed 
When an international class action is initiated in the United States on the basis of international law violations, a tremendously complex and expensive procedure is initiated. Class actions are carried out on behalf of the so-called "named plaintiffs." A "putative" class action implies that after the preliminary issues are addressed, assuming that the motion to dismiss is denied, the class must be "certified" in order for the "putative" class to become a recognized one.

Because of the attractive force of the American courts for international forum shoppers, and because of the traditional reluctance of U.S. courts (motivated by the rhetoric of international human rights and by notions of jus cogens) to give up jurisdiction in favor of foreign courts, a quite interesting phenomenon can be detected. Concepts and notions that are inherently American become part of the common vocabulary and culture of the international legal practice, even when it is carried on by lawyers belonging to civil law jurisdictions.

The way choice of law is handled offers yet another glimpse into how strength easily turns into arrogance, as well as into the unprincipled way in which hegemonic power is exercised. As is well known by any lawyer involved in international legal practice, the choice of substantive law might be a crucial factor for forum shopping. American choice of law rules are considered very advanced, and the Americans are considered world masters in the field of private international law because the choice of law issue has always been part of their everyday practice of the law. The American conflict of law system is based on the fundamental idea that the legal system with the more intense contact with the transaction should prevail. ${ }^{156}$ It is, however, also very sensitive to the idea that the commonalities between legal systems should be exploited in order to obey a notion of judicial economy. ${ }^{157}$ Hence a strong functionalist flavor points at not bothering to belabor foreign law too much when the results of its application would not be so different from those that would be reached by the application of U.S. law.

The complex American litigation on international law is so far removed from the due process standards of most non-American jurisdictions that it is very unlikely that any court of the world would enforce most of the judgments

administrative protection has proven effective in environmental law, and it can be much less expensive to deal with these problems proactively than to approach them in the adversarial posture of U.S. litigation.

156. See EUGEN F. SCOLES ET AL., CONFLICT OF LAWS 68-102 (3d ed. 2000).

157. See id. at 538 . 
entered in the United States against non-American defendants for disputes that arise abroad. In Europe, for example, we are used to a notion of due process that is not limited to the idea that plaintiffs should have tremendously strong tools in order to vindicate their rights. Europeans believe that the possibility of a defendant being innocent entitles them to due process guarantees as well. Nevertheless, many defendants in the global world have significant assets in the United States and wish to avail themselves of business opportunities in the there. Hence, the jurisdiction of U.S. courts is, in some sense, voluntarily accepted by defendants for economic if not for legal reasons.

As discussed in the previous sections, the reaction to hegemonic practices has the potential to become counter-hegemonic. Indeed, there is no lack of evidence of such use in the United States today. Litigants contesting unfair labor practices abroad and environmental issues of global concern are often attracted to U.S. courts, thanks to the pro bono activity of so many social activist groups. Nevertheless, such commendable activity ends up even more strongly asserting the idea that U.S. courts of law are natural and effective adjudicators of world grievances, and that they can serve as alternatives to political struggle and revolutionary practices to make a better world. Whether an inherently conservative judiciary can make good law for progressive purposes is a question that remains open. U.S. courts of law might end up serving as monitoring agencies of governments abroad, arbitrarily holding them to standards that are very different from those respected at home. ${ }^{158}$

There is no system in the world in which courts of law are as effective agencies of rights enforcement as in the United States. If decisionmaking authority in a shrinking public domain is transferred to ineffective rights enforcers, what follows is lawlessness and the rule of the stronger market actor. The globalization of the reactive philosophy thus makes the periphery the ideal marketplace for predatory and opportunistic international capital. It is already a fact that international corporate capital is much more careful in its action within the domestic United States than abroad. While it can always be sued domestically, if its abusive activity is carried on abroad, jurisdictional barriers make the possibility of being sued less certain. American courts of law keep the power to intervene, but they do so only selectively, skilfully playing with

158. The U.S. record regarding human rights is very poor from the European perspective. The death penalty and the Guantanamo cages are icons of such double standards. Moreover, the Florida recount saga makes it difficult for U.S. observers to press for fair elections worldwide. 
notions of international comity when they wish not to offer an effective forum for plaintiffs.

Hegemonic and counter-hegemonic forces are not active only in contexts of reception. They appear tremendously present even in the context of production, where the very same global economic actors struggle to make the United States a better place for carrying on their business. The tort reform movement shows how anti-plaintiff activity can be strong even in the United States. ${ }^{159}$ Many recent changes in U.S. legal practice point to a reduction in the power of the private bar in favor of more the harmonious practices of case management or alternative dispute resolution schemes. The same forces that profit from the reactive philosophy and from the reduction of the public domain proactively cured by State institutions also push in favor of changes in the United States, aimed at controlling the potential counter-hegemonic use of courts of law in order to vindicate rights of the weak before the strong. Thus, while the European way of thinking and rhetoric about adversarial decisionmaking becomes more American (Italy is a very interesting example of this phenomenon), the American one, because of the domestic impact of the "antilaw movement," becomes more harmonious and less effective in the protection of rights. Thus "convergence" in legal procedure in the present phase shows the triumph of the worst of the two worlds as the dominant global model of decisionmaking.

\section{U.S. HEGEMONY IN THE EUROPEAN CODIFICATION PROCESS ${ }^{160}$}

In the previous two sections, I have discussed in some detail patterns of Americanization in legal scholarship and case law. I wish now to complete this cursory panorama of the main sources of law by focusing on legislation. Instances of the influence of U.S. law on legislation in Europe are not difficult to detect. ${ }^{161}$ Strict standards of liability for manufacturers are a standard

159. See generally NADER, supra note 154.

160. This section is based on Ugo Mattei, Hard Code Now!, 2 Global JURIST FronTIERS (2002), at http://www.bepress.com/gj/frontiers/vol2/issl/artl.

161. The variety of channels by which the very same pressure groups that affect WTO legislation are also effective at the European level in drafting self-serving law is exposed by GEORGE, supra note 14. See also Alessandro Somma, Tutte le strade portano al Fiume. $L$ 'involuzione liberista del diritto comunitario, in RIVISA CRITICA DEL DIRITTO PRIVATO 263 (2002). 
example in the comparative law literature. ${ }^{162}$ I wish here to focus on the very core of European legislation: the Code.

There is no European Civil Code in place, of course, but there is a widespread debate on whether there should be such a Code, and what it should look like. European civilians, world masters of codification since Napoleon, and world exporters of Civil Codes through the ages, have been receiving and accepting advice from the hegemonic U.S. system, even in the most culturallyloaded aspect of their theory of the sources of law.

The traditional idea of codification, which is the product of NineteenthCentury modernist grand style, and supported by a transcendent idea of sovereignty vested in the State, is a comprehensive, territorial, systematic body of private law rules claming quasi-constitutional status in the edification of the bourgeois legal order. ${ }^{163}$ Codes are to be applied and enforced by subordinate institutions of the legal order. ${ }^{164}$ The main function and posture of civil codes in the civilian imagination is that of the gravitational center around which the legal system rotates. In this conception, a civil code is no ordinary piece of legislation, even though its formal status among the sources of law is the same as any other legislative enactment. Civil Codes in Europe have been deeply political and symbolic enactments. For example, the French Code Napoleon of 1804 contained the translation of the constitutional values of the bourgeois revolution into professional law. ${ }^{165}$ The German Bürgerliches Gesetzbuch of 1900 was the symbolic manifesto of the rebirth of the German Empire, incorporating much of the conservative Kantian philosophy. ${ }^{166}$ The Italian Civil Code of 1942 reflected the political attempt of fascism to break with the individualistic values of the bourgeoisie in favor of a state inspired, authoritarian social model of economy known as "corporativism." The Mexican Civil Code of 1950 and the Eastern German Civil Code of 1975 both attempted to reflect the political values of the socialist revolution into private law.

162. See SCHLESINGER ET AL., supra note 32, at 251-53. Much of newly enacted European economic legislation, from corporate governance to antitrust, shows the impressive impact of Americanization. These fundamental developments in the economic setting of business activity confirm the theory that economic actors are at play to create a familiar business environment, profiting at the same time from the fundamental weakness of legal effectiveness at the periphery.

163. See generally JEAN-LOUIS HALPERN, HISTOIRE DU DROIT PRIVE FRANÇAIS DEPUIS 1804 (1996).

164. See generally Antonio Gambaro, Codice Civile, in Digesto IV Discipline Privatistiche, Civile (1988).

165. See SCHLESINGER ET AL., supra note 32, at 731 -32 (1998).

166. Id. at $236-38$. 
Present day codification proposals are much more cautious, less ambitious and generally discussed as politically neutral. ${ }^{167}$ They are limited in scope, as today we are reduced to discussing whether contract law should be codified. ${ }^{168}$ They are presented, borrowing from U.S. style, as "model codes" or "restatements." Notions such as "soft law," "creeping codification," "open texture," and "bottom-up," entirely foreign to the European legal vocabulary, are used. ${ }^{169}$ Such proposals are to be "interpreted," "discussed," "considered," and "harmonized" by a variety of other sources of law. ${ }^{170}$

Scholarly reaction was lukewarm when, in 1989, the Strasbourg Parliament, the only democratically representative institution of the European Union, for the first time recommended action in the domain of civil codification. ${ }^{171}$ This attitude is shared today by a number of scholars who have expressed severe criticism to the recent, quite detailed discussion of the subject matter, offered by the Direction General 24 of the European Commission. ${ }^{172}$

True, some Codification proposals have been advanced by self-appointed groups of scholars, and some of this activity (such as that of the so-called Lando Commission) has been indeed successful in seizing the stage of European private law. Nevertheless, perhaps because of a more rooted positivistic imprint in European legal scholarship, the issue of legitimacy quickly arose and even such self-appointed groups, lacking any political legitimization whatsoever, have made it clear that their product had little in common with the traditional idea of codification. ${ }^{173}$ The debate over the

167. See V. Zeno-Zencovich, The European Civil Code, European Legal Traditions and Neo Positivism, in IL CODICE CIVILE EUROPEO; MATERIALI DEI SEMINARI 375 (G. Alpa \& N. Bucicco eds., 2001).

168. See generally W. Van Gerven, L' harmonization du droit des contrats en Europe: Rapport introductif, in L' HARMONIZATION DU DROIT DES CONTRATS EN EUROPE (C. Jamin, D. Mazeaud eds., 2001).

169. See Christoph U. Schmid, Beyond the Common Market-Codification of European Contract Law, Paper Presented at Institute of International Economic Law Conference "Function and Future of European Law," Helsinki, (1999).

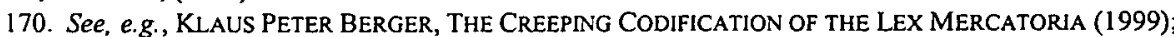
Anothony P. Chamboredon, The Debate on a European Civil Code: For an "Open Texture", in THE HARMONISATION OF EUROPEAN PrIVATE LAW 63-69 (Mark van Hoeke \& François Ost eds., 2000) [hereinafter THE HARMONISATION OF EUROPEAN PRIVATE LAW].

171. See for example H. Koetz, Comparative Legal Research and its Function in the Development of Harmonized Law: The European Perspective, in DE LEGE, TOWARDS UNIVERSAL LAW (Nils Jareborg ed., 1995).

172. See Hugh Collins, Transaction Costs and Subsidiarity in European Contract Law, Paper Presented at the Society of European Contract Law Conference "Communication from the Commission on European Contract Law," Leuven (Nov 30, 2001), at http://www.secola.org; see also Hugh Collins, Formalism and Efficiency: Designing European Commercial Contract Law, 8 EUR. REV. PRIVACY L. 211 (2000).

173. U.S. influence evidently stays behind proposals of "restatement" of European law, notions of "model" European codes, theories of competition between national legal systems as an efficient partern of private law 
function of and need for a Civil Code for Europe is carried on almost entirely within a U.S.-inspired "technological" framework of discussion about the law.

Postmodernism is the logic of late capitalism. ${ }^{174}$ Postmodernist legal discourse gives up claims of universality, objectivity, and monism. ${ }^{175}$ The nation-state blurs, sovereignty is decentralized, and legal propositions cannot be legitimized in terms of right or wrong. Justice becomes relative, and efficiency becomes expediency, pragmatism, and strategy. ${ }^{176}$

"Avant garde" jurists have claimed that the law is the domain of professionalism, culture, and technique. ${ }^{177}$ Jurists have finally rid themselves of positivism, state-centrism, and dogmatism in legal reasoning. Legal style has become a pastiche of different modes of thought-many times borrowed from experiences of different domains of knowledge or of different legal experiences. ${ }^{178}$ Political legitimacy is the last of concerns. If legal reasoning is a technique of argumentation, a battle of hired weapons, there is no space for the myth of political representation. Such mode of thought, interestingly borrowed from French leading philosophers such as Sartre, Derrida, and Lyotard, ${ }^{179}$ has characterized American legal thought from the last decade of the Twentieth Century. ${ }^{180}$ Its reception in the European debate on codification, in addition to demonstrating the unprecedented influence of contemporary U.S. law, shows in action how the building of a second nature, due to the U.S.

integration, and notions of facilitating optional "default law" as an efficient alternative to mandatory binding legal rules. See, e.g., THE COMMISSION OF EUROPEAN CONTRACT LAW, PRINCIPLES OF EUROPEAN CONTRACT LAW PART I: NON-PERFORMANCE AND REMEdies (Ole Lando \& Hugh Beale eds., 1995). For another viewpoint, see Giuseppe Gandolfi, Pour un code européen des contrats, 91 REVUE TRIMESTRIELLE DE DROIT CIVIL 707 (1992). The first significant results of the Pavia Group are contained in CODE EUROPÉEN DES CONTRATS-AVANT PROJECT (Giuseppe Gandolfi ed., 2001). For a recent articulated proposal that is gaining currency in the European debate, see C. Von Bar \& O. Lando, Communication on European Contract Law: Joint Response of the Commission on European Contract Law and the Study Group on a European Civil Code, 10 EUR. REV. PrivaCY L. 183 (2002).

174. See Fredric Jameson, POSTMOdernism, OR, THE CUltural Logic of LATE CAPITAliSM (1991); HARVEY, supra note 97; see also JEAN FRANÇOIS LYOTARD, THE POSTMODERN CONDITION: A REPORT ON KNOWLEDGE (1984) (where he defines postmodernism as an "incredulity towards metanarratives").

175. See generally Mattei \& di Robilant, supra note 123.

176. See MERCURo \& MEDEMA, supra note 116; see also RICHARD POSNER, FrontiERS OF LEGAL THEORY (2001).

177. See, e.g., GUNTHER TeUbner, LAW AS AN AUTOPOIETIC SySTEM (Anna Bankowska \& Ruth Adler trans., 1993).

178. See generally MNDA, supra note 116.

179. Lyotard is responsible for introducing the term "post-modern" into critical philosophy. See LYOTARD, supra note 174.

180. See FELDMAN, supra note 116. 
"technological" conception of law, works outside the very specific U.S. institutional setting. ${ }^{181}$

On the continent, post-modernist legal discourse has intruded on the dominant position of legal scholarship among the sources of law. ${ }^{182}$ The law has long been the domain of jurists in Europe, an elite of sophisticated intellectuals traditionally legitimized by knowledge and scholarship. ${ }^{183}$

Seen from the perspective of hegemony, it is difficult not to observe that, together with the last wave of U.S. legal influence, the European debate over codification shows a real change in the relationship between the law and the market. Both the soft "cultural" attitude, typical of postmodernist scepticism, irony, and loss of faith, ${ }^{184}$ and the technocratic approach proper of mainstream U.S. legal thinking are functional to a new legal and economic order in which the market governs the law rather than the other way around. ${ }^{185}$ It is no surprise that, within this paradigm shift, ${ }^{186}$ the model code that has been able to seize the stage of the spectacle has been the Uniform Commercial Code. This U.S. example, which shares very little with the Civilian idea of codification (and which in turn shows some German influence), was consciously pursued by its "inventor" Karl Llewellyn as a professional project of merchants, with very little in common with the core "political" project of a civilian civil code.

In order to be successful, legal institutions competing with strong economic actors need to be strong and highly effective. The stronger the actors, the stronger the institutions must be if individual selfishness and interest are to be channelled for the general welfare. ${ }^{187}$ The rhetoric about the efficiency of soft law has to be exposed in order to anticipate the impact of the Europeanization of private law. ${ }^{188}$ I submit that emphasis on softness in the making of European private law is likely to mean lawlessness and a free battleground for exploitive business interests.

181. Martin Heidegger warned about the "technological" influence on systemic pattems of thought and the resulting technocratic culture. See HEIDEGGER, supra note 8 . It remains a recurring and important theme in continental European philosophy.

182. See Mattei \& di Robilant, supra note 123, at 1054.

183. See Antonio V. Gambaro, Western Legal Tradition, in THE NEW PALGRAVE, supra note 1, at 686.

184. See, e.g., Pierre Legrand, Against a European Civil Code, 60 Mod. L. ReV. 44 (1997).

185. See ANDERS STEPHANSON, MANIFEST DESTINY: AMERICAN EXPANSIONISM AND THE EMPIRE OF RIGHT (1995); see also SASKIA SASSEN, LOSING CONTROL? SOVEREIGNTY IN AN AGE OF GLOBALIZATION (1996).

186. See Mattei, supra note 160.

187. See Charles L. SChUltze, The PUblic USE OF PRIVATE INTEREST 1-15 (1977).

188. Such predictive function is crucial to the comparative legal and economic analysis. See generally Mattei \& Monti, supra note 113. 
Mathias Reimann has suggested that the U.S. model should be thoroughly appraised. ${ }^{189}$ To be sure, because soft law is an American metaphor, we need to place it in context. Scholars have trained us to understand that transplants of legal institutions are not like exports of commodities. ${ }^{190}$ Both the contexts of reception and origin are highly relevant in predicting what is likely to happen. The present day European context could not be more different than the context of U.S. law, where restatements and model codes have been suggested and developed as soft law alternatives to hard law since the 1930 s. ${ }^{191}$ The United States of the Twentieth Century was indeed the institutional system with the strongest judiciary in the history of humankind. The decisions of the U.S. judiciary, reinforced by stare decisis, have never been perceived as soft. ${ }^{192}$ The American judiciary's role in the process of making the general rules of the game has always proved stronger than the role of legislators. Statutory law, in fact, could never do much more than suggest piecemeal changes. ${ }^{193}$ Soft law in the U.S. never undermined, either rhetorically or in substance, the main actors of the legal system, who are the legitimated forces of control of the public sphere on the economic behavior of market actors. ${ }^{194}$ In Europe, such a background scenario of strong self-legitimized institutional actors with inherent powers to channel individual economic self interest in directions compatible with the public welfare is simply absent. ${ }^{195}$

A soft Europeanization of private law lowers responsibility for national legal systems, persuaded as they are of the existence of another level of the legal system that is "better located" to monitor global transactions. ${ }^{196}$ The soft discourse at the European level undermines the prestige of national civil codes, which are considered obsolete and out of fashion precisely because they are

189. Reimann, supra note 105.

190. See, e.g., GRANDE, supra note 8; see also Alan Watson, Legal Transplants and European Private Law, 4.4 ELECTRONIC J. COMP. L. (2000), at http://www.ejcl.org/44/art44-2.html.

191. See GRANT GILMORE, THE AGES OF AMERICAN LAW 72 (1977).

192. See generally HART \& SACKS, supra note 109.

193. Compare J.N. Pomeroy, The True Method of Interpreting the Civil Code, 4 W. COAST REP. 585 (1884) with GUIDO CALABRESI, A COMMON LAW FOR THE AGE OF STATUTES 1 -7 (1982) (a more recent account). 194. See generally DUNCAN KENNEDY, A CRITIQUE OF ADJUDICATION: FIN DE SIÈCLE (1997) (discussing the use of such power by U.S. courts).

195. See generally HERBERT JACOB ET AL., COURTS, LAW, AND POLITICS IN COMPARATIVE PERSPECTIVE (1996).

196. See generally LUISA ANTONIOLLI DEFLORIAN, LA STRUTTURA ISTITUZIONALE DEL NUOVO DIRITTO COMUNE EUROPEO: COMPETIZIONE E CIRCOLAZIONE DEI MODELLI GIURIDICI (1996); See also generally Roger Van den Bergh, The Subsidiarity Principle in European Community Law: Some Insights from Law and Economics, I MAASTRICHT J. EUR. \& COMP. L. 337 (1994). 
hard. ${ }^{197}$ However, such national civil codes are the only source of principled legitimacy of judicial power in present day Europe. Thus their cultural undermining is a blank check to corporate rapacity.

It is not difficult, in conclusion, to see that the Americanization of the codification process weakens European institutional effectiveness. It shifts the balance of power even further in favor of the United States, which is incrementally becoming the only effective legal system in the global marketplace. More and more plaintiffs will try to litigate in the United States as defendants continue to try to keep the cases in Europe. While American courts will experience the luxury of deciding which cases to entertain, and American law the luxury of providing the standards of responsibility worldwide, corporate market actors, the real beneficiaries of the neo-American model of capitalism, will have in Europe a giant market to exploit with very limited local restraints. The only limits might be imposed at the center, if the American judiciary is willing to do so.

\section{CAPITALISM V. CAPITALISM: EFFICIENCY IN LEGal TRANSPLANTS REVISITED}

In the course of twenty years, the fundamental characteristics of U.S. law, by a process of naturalization and of technological transformation of the legal discourse, have ceased to be seen as one possible path in the law and, having turned into imperial law, have been able to assert themselves as the only alternative in global society. ${ }^{198}$ In the making of such imperial law, alternative models foreign to the U.S. cultural imprinting have been abandoned or unable to develop fully because of the irresistible force of U.S. legal expansionism, which is grounded in a "market prone" reactive philosophy. Such alternative models might be seen as patterns of resistance, in the sense that they reflect deep traditional characteristics of what is now a new periphery, hastily abandoned to follow models produced at the center. Such counter-forces ${ }^{199}$ have different characteristics and different degrees of intensity. The aggregate of such counter-trends roughly outlines a possible alternative model that shows

197. See generally Geoffrey Samuel, English Private Law in the Context of the Codes, in THE HARMONISATION OF EUROPEAN PRIVATE LAW, supra note 170, at 47; Chamboredon, supra note 170, at 64 . 198. GRANDE, supra note 8 (showing that this process happens in the domain of criminal procedure).

199. Pierre Bourdieu, OUtLINE OF A TheORY OF PraCtice (Richard Nice trans., 1977). 
some interesting features for the development of an antagonistic alternative to the present path of legal globalization. ${ }^{200}$

The previous cursory analysis of the recessive trends in the process of Americanization of European law offers the traits of a European social way, grounded in the central position of the welfare State, in which the public domain and the domain of politics seem much broader than the private domain and the domain of the market. As a model of economy and development, the European "social way" was discussed during its political dismantling by French economist Michel Albert, in his classic discussion of what he calls the "Rhine capitalist model" developed in Germany, Scandinavian countries, Holland, Switzerland, and Japan in the aftermath of World War $\Pi{ }^{201}$ This model, that we will simply name "social capitalism" (as opposed to neo-American or imperial capitalism), deserves a closer look, because it sheds light on the possibilities and limits of counter-fires in the process of the making of imperial law.

The social model of capitalism, according to Albert's analysis, shows notable efficiency as compared to the Neo-American alternative, based on the surrender of the state structures to private capital and short-term financial interests. Albert finds the following benefits of the social model over the American model: the stabilizing intervention of the State; the strong role of trade unions in the creation of a secure and stable marketplace in which workers develop patterns of loyalty to their employer; a public sector of welfare assistance capable of limiting the costs of social exclusion; a strong system of public education and scientific research that does not penalize areas of knowledge that are incapable of attracting private investment; ${ }^{202}$ and a conception of the corporation as a durable relational institution that the State will protect, in consideration of the protection that such an institution offers to its members. Albert argues that these factors make the social model preferable in terms of economic efficiency as well as social justice. ${ }^{203}$

200. A collection of papers devoted to globalization seen from the perspective of the losers in the process can be found in the Symposium Globalization at the Margins. Perspectives on Globalization from Developing States, 7 IND. J. Global LeGal Stud. 1 (1999). See also VIEWS from the SOUTH: THE EFFECT OF GLOBALIZATION AND THE WTO ON THIRD WORLD COUNTRIES (Sarah Anderson ed., 2000). 201. See ALBERT, supra note 10, at 127-90.

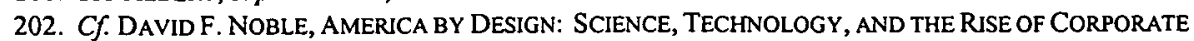
Capitalism (1977).

203. The outcome of such an aggregate of factors is a major increase of family savings in the countries following the social altemative between 1980 and 1990 as opposed to a decrease of the same figures in the United States. See ALBERT, supra note 10, at 191-210. For updated information, see TABB, supra note 2. 
Albert presents the social alternative and Neo-American model as two structures of capitalism competing fiercely with each other. Albert adopts an old metaphor of Schumpeter, according to whom "It is thanks to the brakes that cars can go faster." Applying this image to his analysis of the two capitalisms, Albert concludes ${ }^{204}$ that it is thanks to the brakes imposed by the public powers and the civil society that the best economic development can be obtained. The impressive amount that the French economist offers allows him to conclude that "it is not true that economic efficiency requires social injustices... . Between justice and efficiency exists a strong integration today more than ever; we found it in all countries following the Renanian model."205

Historically, capitalism has evolved and diffused itself mostly by means of one of the most traditionally studied market failures: externalities. There is a pattern of development based on leaving the social costs where they fall. ${ }^{206}$ Presently, such social costs are produced mostly by environmental catastrophes and labor exploitation of women and children. Reactive institutions-local, foreign, or transnational-are simply incapable of handling the tremendous pressure that any attempt to internalize such externalities produces for institutional actors. Two recent papers, devoted to the Bophal catastrophe ${ }^{207}$ and to the market for toys, ${ }^{208}$ dramatically demonstrate the incredibly complex aggregate of interests and "technical problems" that make it impossible for reactive institutions to attempt internalization.

Imperial law is an institutional setting that does not compel market actors to internalize their social costs. ${ }^{209}$ No efficient economic system lives outside of an institutional setting. ${ }^{210}$ Promoting reactive institutions as the only alternative takes away the very features of the legal system that might internalize externalities, and as a consequence, ground an efficient economic model.

204. ALBERT, supra note 10 , at $127-28$.

205. Id. at 128 (translation from Italian mine); Within a school of thought more familiar to the American readership, G. Calabresi argues, developing on the notion of merit goods, the necessary integration between distribution and efficiency in public policymaking. See Guido CALABresi \& PHILIP BOBbITT, Tragic CHOICES (1978). Mainstream law and economics, to the contrary, follows the traditional economist's rhetoric of a full separation between the domain of distribution and the domain of efficiency. See RICHARD POSNER, ECONOMIC ANALYSIS OF LAW (5th ed. 1998).

206. For a critical discussion, see generally J.M. BLAUT, THE COLONIZER'S MODEL OF THE WORLD: GEOGRAPHIC DIFFUSION AND EUROCENTRIC HISTORY (1993).

207. See M. Galanter, Law's Elusive Problem: Learning from Bophal, in TRANSNATIONAL LEGAL PROCESSES, supra note 1, at 172.

208. Snyder, supra note 2.

209. See supra Part II.B.

210. See generally DOUGLASS NORTH, INSTITUTIONS, INSTITUTIONAL CHANGE AND ECONOMIC PERFORMANCE (1990). 
In the absence of high transaction costs limiting their diffusion, efficient legal solutions would be dominant in the global marketplace of legal ideas. ${ }^{211}$ If such an analysis could be extended more generally to political and economic institutions, one should see a major diffusion of the more fair and efficient social capitalism and a concomitant incremental recession of the neo-American model, yet this is far from being the case. According to Albert:

In the very moment in which the neo-American model proves to be less efficient than the social model, it nevertheless succeeds in gaining a competitive advantage from the political and ideological perspective. . . . Because of the fact of the social and economic superiority of the social model we could expect to see it triumph also on the political ground.... [T] very contrary is happening. The social model is literarily overwhelmed by the political and cultural influences of its American competitor and as a matter of fact it is progressively left behind from the political perspective. ${ }^{212}$

The dismantling of the social model means abandoning the proactive role of the government in the economy in favor of a reactive one. The decline of a proactive role of the government in the economy necessarily transfers decisionmaking authority to its reactive institutions, i.e. courts of law. In continental Europe, perhaps for the first time, the logic of public law is yielding to that of private law, so that a process of hybridization of the two traditionally separate areas of legal knowledge is taking place. ${ }^{213}$

As proactive institutions are dismantled, there is the need for stronger reactive ones, ${ }^{214}$ or total lawlessness follows. Nevertheless, Albert's analysis

211. See Mattei, Efficiency in Legal Transplants: An Essay in Comparative Law and Economics, 14 INT'L REV. L. \& ECON. 3 (1994). The ideas developed in that paper have gained some currency in the debate on European codification of private law, where, particularly in the last few years, one can see an attempt to "select" the rules to be included in the code on the basis of technical reasons such as efficiency. See the discussion supra Part VIII.

212. See ALBERT, supra note 10, at 244 (translation from Italian is author's).

213. The large number of new "authorities," from privacy to telecommunications, both at the European level and at the level of member states, are applying the logic of private law and function in a remarkably similar way to that of their American counterparts. For the first time in their history, European private lawyers (and ordinary courts) have ceased to believe that there is another direct circuit of decisionmaking dealing with the public domain so that some public policy concems emerge in the private law reasoning. See generally HESSELINK, supra note 107.

214. Weak reactive institutions are a problem only because of the dismantling of the strong proactive institutions. A rush to upgrade courts of law and to modify the pattem of legal reasoning in private law, 
shows that, from the efficiency perspective, the dismantling of the proactive institutions of the social model of capitalism should be questioned. Such questioning does not occur because of the process of cultural influence and hegemonic rule that the American model has been able to create. Once the consequence of the problem (the increasing role of reactive institutions) is identified as the problem itself (reactive institutions in the periphery are weak) there is no question that American law is able to offer an apparently efficient institutional setting to imitate.

\section{$X$ THE "SPECTACLE" AND "COUNTER-FIRES"}

Albert is no radical. He considers the global spread of less efficient neoAmerican capitalism as a paradox. He tries to explain this spread using notions of seductiveness and appeal, drawing on the intrinsic characteristics of the neoAmerican model as a success story of the risk-taking, gambling and glittery lifestyle. ${ }^{215}$

In the radical analysis of French revolutionary thinker Gui Debord, ${ }^{216}$ one finds a thoroughly developed theory capable of explaining the present path of the law. Within Debord's analysis, it seems possible to solve the fundamental puzzle approached in this essay: the relationship between the American and the imperial model.

In 1967, Debord described, in quite difficult language, two models of spectacular society: the diffused model of the capitalist economy, and the

therefore, is a necessity only when the logic of the dismantling is already accepted. Interestingly, the weakness of courts in the Third World (meaning the difference of adjudicatory models from that of the United States) is considered by the World Bank to be the main problem in the law, to be targeted through structural adjustments programs. This obsession with the progression from legality to development to courts of law (or ADR devices) can be perceived in all its pervasiveness by looking at the papers included in the annotated bibliography offered by the website of the World Bank devoted to legal development. For a critique of ADR as yet another institution based on the dominance of imperial law, see Laura Nader \& Elisabetta Grande, Current Illusions and Delusions in Conflict Management: In Africa and Elsewhere, 27 L. \& SOC. INQUIRY 573 (2002).

215. Cf. ROBERT H. FRANK \& PHILIP COOK, THE WINNER TAKE ALL SOCIETY: WHY THE FEW AT THE TOP GET SO MUCH MORE THAN THE REST OF US (1996).

216. This remarkable intellectual, fierce enemy of Sartre and Lyotard (excluded, for this reason, from the inner circles of French militant intellectuals), used to say that he considered it vulgar to be an authority in social critique rather than being an authority in the system criticized. His book, The Society of the Spectacle, was first published in 1967, and though almost never cited was remarkably influential. It was updated in 1988 with an essay that develops a full-fledged theory of what he calls the "integrated spectacle" as the model of social and economic domination of the post cold-war. See DEBORD, supra note 40. 
centralized model of the communist alternative. ${ }^{217}$ The end of the Cold War, Debord argued as early as 1988, has produced a hybridization of the two models, with the spectacular notion of freedom, typical of the capitalist alternative, merged with the repressive and authoritarian conception of order proper of the Stalinist spectacle. This "integrated spectacle" makes the apparent opposites live in the same spectacular body. Highly dramatic economic adventures in which the spirit of freedom gets exalted coexist with highly dramatic and spectacular exercises of repression in which the forces of the all mighty Empire become the object of cult. ${ }^{218}$

Debord is not alone in emphasizing the role of media and of the spectacular dimension in the present phase of world history. For example, Jean Beaudrillard, in his book The Perfect Crime, and Pierre Bourdieu, in a variety of recent interventions, both stress the impact of television and spectacular models on notions of representation and democracy. ${ }^{219}$ Using the notion of spectacle is thus very tempting in exploring globalization and hegemony in legal consciousness, particularly in attempting to shed light on the phenomenon that puzzled Albert, expansion of a less efficient alternative.

One may argue that the only way to create an efficient setting for the global market is to develop a thorough and efficient global system of control of externalities, something that requires mighty, proactive institutions in order to be at all efficient. Nevertheless, the alliance between strong international market actors and the reactive legal philosophy functional to their needs is what gives the U.S. legal consciousness the comparative advantage that produces its success. Short-term benefits typical of financial market capitalism do not require externality controls, because it is exactly the possibility of capitalizing here and now, with long term externalities imposed on the periphery, that explains its spectacular appeal. ${ }^{220}$

World renowned Italian economist Carlo M. Cipolla explains the tension between short-term and long-term efficiency thus: "The history of our happy generations can be shortly described as follows: for millions and millions of years a treasure has been accumulated. Then somebody in the family has discovered the treasure and started to dissipate it. Humankind today is living in a period of tremendous dissipation. In a single year we consume more coal

217. DEBORD, supra note 40, at 193.

218. Id. at 193; see also EDWARD S. HERMAN \& NOAM CHOMSKY, MANUFACTURING CONSENT (1988).

219. See supra text accompanying note 20.

220. It is too easy to show in the recent Enron and WorldCom disasters the impact of the strategy of privatizing controls. 
than how much it is produced in one hundred centuries of natural formation of solid consumable energy sources."221

The institutional setting of the imperial marketplace, short of being more efficient, seems only to be better adaptable to the needs of short-term exploitation of the treasure accumulated in millions of years. Of course, energy consumption is not at all equally spread in the world, and the United States is on the top of the list of energy consumption. Consuming energy is a highly spectacular activity. It is a form of common sense to credit to the spectacle of consumption the fall of the Soviet Empire.

Law is a cultural aspect of any society. A spectacular society is likely to produce spectacular law. ${ }^{222}$ If it is true, as Freud once apparently said, that exaggeration is a key to success and leadership, ${ }^{223}$ there is little question that U.S. law has been capable of exaggerating the fundamental aspects of western law, making them highly spectacular: judges challenge the political power and re-write the history of their country; rights are enforced without frontiers; lawyers are portrayed as living success stories; scholars are engaged in highly creative intellectual exercises with little restraint from the actual technicalities of the law; ${ }^{224}$ electoral processes are organized as time-circumscribed displays of personality cults; there is spectacular assertion of the institutional power of life and death; and the law is glamorized in movies, best sellers, and television shows featuring glittering and highly photogenic police cars. All of these are

221. Carlo M. Cipolla, Uomini, TECNiChe, ECONOMie 61 (1983).

222. See Anna di Robilant, The Aesthetics of Law, 1 GloBal JURIST AdVANCES 1 (2001), at http:// www.bepress.com/gj/advances/voll/iss2/art 1; Pierre Schlag, The Aesthetics of American Law, 115 HARV. L. REV. 1047 (2002).

223. Interview with David Daube, Professor Emeritus of Law, Univ. of Cal. Berkeley, in Berkeley, Cal. (1990).

224. Even the model of a German professorial career-long, boring, and demanding because of the duty to write the habilitation-shrift-is short-circuited. Young German academics are offered chairs in the United States, are Americanized in their ways of thinking, and might be directly called to German Universities without habilitation if one day they wish to do so. It is easy to demur on the point that the European model of procedure, with the extensive role of clerks in service of process and in discovery, and an emphasis on written rather than oral confrontation, is less exciting than the American fishing expeditions, tournaments of resume in scientific evidence, and cross examination of witnesses in the hands of a flamboyant bar. Imagine how boring would be a movie about a German attomey, most of the time sitting in his office, writing a brief with his copy of the Konmmentar at hand! Some data are offered by Wolfgang Wiegand, The Reception of American Law in Europe, 39 AM J. COMP. L. 229 (1991); see also YVES DEZALAY \& BRYANT G. GARTH, DEALING IN VIRTUE: INTERNATIONAL COMMERCIAL ARBITRATION AND the CONSTRUCTION OF A TRANSNATIONAL LEGAL ORDER (1996) (an influential sociological study on a new-born class of transnational lawyers). 
aspects of the law "going pop,"225 abandoning the dusty Kafkian bureaucratic scenarios to be promoted as part of the imaginative domain of the integrated spectacle.

Thus, what becomes global is not so much the effective, binding, and nittygritty American law, but rather its spectacular aspects. It is not efficiency but the spectacle of efficiency; it is not the actual organization of justice but the spectacle of justice. ${ }^{226}$ Impoverished public institutions of the welfare state, in health care as well as in education, are compared to private ones using standards that always make public works look worse. ${ }^{227}$ The proactive institutions of governance, staffed with underpaid personnel, are depicted as "bureaucracies" and become less and less attractive to bright global young people.

To be sure, the analysis cannot remain on the merely technical level of lawyer's discourses. The law is an intimate part of the "integrated spectacle" and performs a central part in the public political discourse. De Tocqueville noticed its centrality in America two hundred years ago. ${ }^{228}$ Today, this discursive practice of legality is reproduced at the global level and is one of the salient features of imperial law. There is no issue of global governance-from the legality of the war, to legal aspects of global intellectual property rights, to the consequences of non-aligned politics by spectacularly portrayed "rough states"- that is not appraised in legal terms. Such legal terms are of course spectacular, vulgarized, simplified, and exaggerated for the needs of media consumption.

To be entertaining, the integrated spectacle of course requires antagonists, too. The end of communism makes new polarizations emerge. "Capitalism versus socialism" gets transformed in "democracy and the rule of law" versus "the axis of evil." Comparisons become ideological. Portraits are offered with strong traits. The legal aspects of the first model are promoted and emphasized as fair, efficient, natural, and good. The legal aspects of the second are unfair,

225. See generally Richard K. SHERWIN, WHEN LAW GOES POP: THE VANISHING LINE BETWEen LAW AND POPULAR CULTURE (2000).

226. The legal aspects of the "other capitalism" are dull, which is emphasized in U.S. academia and in the "more advanced" circles of the European legal profession. The traditional German, Italian, or French literary style is perceived as mere "black letter;" it is not creative enough. Conversely, creativity is emphasized in the U.S. academy. See James Gordley, Mere Brilliance: The Recruitment of Law Professors in the United States, 41 AM. J. COMP. L. 367, 369 (1993).

227. It is already accepted as a fact, for example, that in the law school rankings of U.S. News and World Report, the highest rankings are beyond the reach of public institutions.

228. See generally DE TOCQUEVILLE, supra note 27 (main thesis of the book). 
medieval, inefficient, obscurantist, unnatural, and bad. The antagonist changes; the strategy stands still.

Institutional alternatives are politically appraised according to their degree of adherence with the spectacular ideal. What follows is that the U.S. legal system is naturally the leader. ${ }^{229}$ The Latin alternative-with its different pattern of sexual relationships, emphasis on extended family ties, traits of statecentrism and remains of socialism, Mediterranean political sensitivity that is more open and understanding to the fundamental traits of the Arabic world, and less efficient organization of its everyday life - gets portrayed (and sometimes is self-portrayed) as obsolete, untrustworthy, and governed by a fundamentally macho philosophy.

What in this essay I call "Latin resistance," short from being an organized counter-hegemonic force, is a random aggregate of political and philosophic thinking, of political action and of protest, rooted in a radically critical and revolutionary political project. Latin resistance is the radical questioning of a model of development that people increasingly see as arrogant, racist, and ultimately self-destructive for humankind. ${ }^{230}$ Confronted with the Latin resistance, imperial law displays an unprecedented degree of spectacular repression. ${ }^{231}$ The sensitivity of this alternative project is rooted in the dramatic history of de-colonization and, in particular, in the War of Algeria. ${ }^{232}$ In this cultural humus, the question of Islam, and of developing a model of coexistence rather than a clash of civilizations, is inherently solved within the Latin resistance in the refusal of a North-South polarization as a successor of the West-East standoff. The strategy is to develop respect for demographic trends rather than attempting to build useless technological walls. ${ }^{233}$ The strategy is to

229. For a fascinating series of generalizations, see JEAN-PHILIPPE MATHY, FRENCH RESISTANCE: THE FRENCH-AMERICAN CULTURE WARS (2000). For a more specific discussion in the institutional domain, see Judith Beth Prowda, United States Dominance in the "Marketplace of Culture" and the French "Cultural Exception”, 29 N.Y.U. J. INT'L L. \& POL. 193, 200 (1997).

230. For an introduction to such a counter-hegemonic movement, see generally TABB, supra note 2 . See also Democratizing the Global Economy: The Battle against THE World BanK and the INTERNATIONAL MONETARY FUND (Kevin Danaher ed., 2001) [hereinafter DEMOCRATIZING THE GLOBAL ECONOMY].

231. An incredibly brutal repression, most of the time supported by the media, has characterized demonstrations from Seattle to Genoa. See. e.g., T.L. Friedman, Senseless in Seattle, N.Y. TIMES, Dec. 1, 1999, at 23; see also, AA. VV., GENOVA IL LIBRO BIANCO (2002) (pictures and texts on the brutality at Genoa).

232. An event crucial in the development of the political thought of Foucault, Althusser, Derrida and many others, including Sartre. See, e.g., FRANTZ FANON, THE WRETCHED OF THE EARTH 7 (Constance Farrington trans., 1963).

233. Some of these themes can be found in the work of Nobel laureate Amartya K. Sen. 
expose the variety of western colonial strategies used to deny the historical role of the East and South in human civilization, ${ }^{234}$ and in particular to develop a thorough critique of ethnocentrism, both conscious and unconscious. Such ethnocentrism is itself highly inefficient because it reinforces a model of legal development (the present legal agenda of the World Bank, IMF, and WTO) that is rooted in the production of externalities that only highly proactive and politically legitimized strategies of global governance could tackle. ${ }^{235}$

Examples abound of the naturalization of the ethnocentricity that simply precludes legal scholars from seeing macroscopic violations of genuine notions of equality and the rule of law. Take, for example, the production of a toy. Directives on products liability, developed in Europe under the clear influence of U.S. lawyers, ${ }^{236}$ contain one such hidden and technically motivated example of discriminating ethnocentrism. A child that gets damaged by a toy within Europe can seek and find redress in the law. Thousands of children who, during the process of production of the very same toy, are poisoned and have their health ruined, can seek no redress. Arbitrarily, the moment in which a product is considered for the purpose of liability is the moment in which it is introduced in the Western market, reaching the stage of the spectacle.

Many colleagues would argue that these are problems that go beyond the domain of private law. ${ }^{237}$ Indeed, this is exactly my point. There is a need for a shift in mode of thought, to escape traditional taxonomies and ideas. The Latin resistance offers a reservoir of radically critical thinking that needs to be applied to the legal discourse.

Most of the externalities, most of the social costs dumped in the backyard of our weaker neighbors of the South, are created during the process of producing commodities that are consumed mainly by the roughly 300 million people that make up the European market. ${ }^{238}$ Such production is traditionally ignored by private law, concerned as it is only with final outcomes. In economic terms, this simply introduces an alternative. Either European consumers pay too little for their commodities because their prices do not

\footnotetext{
234. See Monateri, supra note 128 (discussing the history of Western legal tradition).

235. See JOSEPH E. STIGLITZ, GLOBALIZATION AND ITS DISCONTENTS (2002) (criticizing IMF policies); see also David Moberg, Silencing Joseph Stiglitz, in DEMOCRATZZNG THE GLOBAL ECONOMY, supra note 230, at 127 (noting that the World Bank's response to Stiglitz' criticism was to let him go as special adviser).

236. This influence is a classic example in comparative law. See generally SCHLESINGER ET AL., supra note 32.

237. A distinguished German colleague made this point at the Max Plank Institute in Hamburg when I delivered part of this paper in May 2002.

238. See generally NAOMI KLEIN, NO LOGO (2000) (discussing such processes of extemalization).
} 
reflect the true social costs of production (environmental damage, labor exploitation, and so forth) and European capitalism is once again subsidized by former colonies, ${ }^{239}$ or multinational corporate logo-lords (mostly European, Japanese, and North American) make unfair profits pocketing the value of such social costs. ${ }^{240}$ In both cases, such an economic reality should be a concern for the European policymaker drafting the rules of the game. Unfortunately it is not, since the rules of the game-in Europe and even more visibly in more remote areas of the periphery - are de facto drafted by the international financial institutions.

Imperial law, and the post-modern, market-friendly ideology that it carries with it, might already be precluding the construction of a European social market as a counter-fire. The tremendous capacity of imperial law to introduce discursive practices that depict legal production as pro-consumer, when it is in fact stimulated by the large international capital, is now beginning to be exposed. ${ }^{241}$ Europe is facing a number of constitutional moments. ${ }^{242}$ It is difficult to evaluate them because the spectacle makes options difficult to distinguish. One can, however, see that some scholarly positions are facilitating the final triumph of imperial law. Following the trend in the Americanized legal landscape, without approaching the real issues of externality control, only confirms Europe as a periphery of the economic Empire. Whether resistance can be organized, and at what level, is more difficult to tell. ${ }^{243}$

\section{The NEXT STAGE: From AMERICAN HegEMONY TO "EMPIRE" IN THE LAW}

Major structural changes are occurring in the assertion of U.S. hegemony. To begin with, the issue of territoriality has made itself dramatically felt, ${ }^{244}$ so

239. See Ania LoOmba, Kolonyalizm, Postkolonyalizm [COlOnialism/PostColonialism] (2000).

240. This is the fundamental thesis of KLEIN, supra note 238 , and of many other critiques of corporate globalization.

241. See GEORGE, supra note 14; see also Allesandro Somma, Il diritto dei consumatori è un diritto dell'impresa, POLITICA DEL DIRITTO 679-88 (1998).

242. See BRUCE A. ACKERMAN, WE THE PEOPLE 165-71 (1991) (exemplifying the notion of constitutional moment); see also J.H.H. Weiler, The Transformation of Europe, 100 Y ALE L. J. 2403, 2407-08 (1991) (in the European institutional context).

243. For a skeptical view of legal scholarship's ability to contribute in the liberating struggle, see MINDA, supra note 116, at 247-57.

244. See generally IMMANUEL WALLERSTEN, THE CAPITALIST WORLD ECONOMY (1979) (asserting that capitalism (the fundamental source of imperial law) has always been the province of the world economy rather than of the nation state). 
that the very idea that the present phase in global legal consciousness is that of a global Americanization has to be approached carefully. In this essay I have suggested that American legal consciousness has permeated what is now a dominant layer of the world legal systems: imperial law.

World interdependence has increased in the second half of the Twentieth Century, the era corresponding with Americanization in the law. Boundaries of knowledge, as well as of territory, have largely collapsed. ${ }^{245}$ In the law, a variety of modes of thought have always competed in history, so that even when one speaks of French or German leadership characterizing the era preceding World War II, some distinctions must be accounted for. ${ }^{246}$ When it comes to the second half of the Twentieth Century, that of U.S. leadership, contaminations appear even more clearly, so that one could argue that U.S. law is in fact the outcome of the merger of the civil law and common law traditions, where traits of originality can be kept visible only by means of some artificial effort. $^{247}$

There are at least two factors to be considered. Issues of resistance, both technical and political, are enriching the picture. From the technical point of view, legal cultures in the world can provide resistance, in the sense that many local legal professionals simply do not have direct access to the American legal discourse. ${ }^{248}$ Many lawyers, even in the former center of the legal world, do not read English language materials, so their perception of U.S. legal consciousness is, at best, filtered.

Many non-American lawyers, imbedded in state-centric positivism, and drawing on local notions of separation of power and political accountability (and legitimacy), simply fail to imagine that certain things can be governed by courts of law. This kind of resistance, sometimes called "legal path dependency," can strongly limit the way in which the imperial layer of the law

245. A general hybridization makes it extremely difficult to keep even ideal types distinct. Thus, the very utility of using ideal types as heuristic devices can, on the one hand, be questioned while, on the other hand, it becomes a most stringent necessity to make sense of an increasing degree of complexity. See HARVEY, supra note 97; see also ANTI-OEDIPUS, supra note 97, at 217-22; LYOTARD, supra note 174, at 30.

246. This phenomenon is stronger if one looks from the perspective of content rather than only from the geographic origins of one mode of thought. The French social model was at least enriched by German contributions, while the Pandectist approach, on whose leadership in the second half of the Nineteenth Century there seems to be agreement, was certainly "contaminated" by contributions from a variety of countries.

247. See the discussion above on the derivative rather than original character of U.S. law. Supra text accompanying notes $29,30,31$.

248. Cf. Elisabetta Grande, Italian Criminal Justice: Borrowing and Resistance, 48 AM. J. COMP. L. 227 (2000). 
erodes local legal sensitivity. Nevertheless, steps in the direction of developing stronger courts of law are very visible throughout Europe and, as part of structural adjustment programs, also through the more traditional periphery of the world. ${ }^{249}$ Captured by the Americanized legal discourse, the periphery of the world attempts to upgrade its institutional setting in order to look as American as possible by emulating the reactive models found in courts of law and academic legal education. ${ }^{250}$ Both these adjustments end up moving in the direction of what anthropologist Laura Nader, linguist Noam Chomsky, and other critical thinkers have significantly portrayed as an anti-international law movement unfolding in present-day American law. ${ }^{251}$ It is the final assault of imperial law on all such institutions of the nation-state that do not fit its profile favoring economic hegemony and global corporate governance. ${ }^{252}$ Institutional discourses that claim the primacy of politics over law are abandoned in favor of aspects that make economic power stronger than a legal order. Scholars have detected this phenomenon in a variety of areas of U.S. law, such as the socalled tort law reform, by which powerful corporate defendants try to emasculate the plaintiffs' bar for fear of class actions and punitive damages. Another example is the shift towards compulsory ADR and the tremendous pressure to settle disputes with the goal of silencing victims of abuse in the workplace or in the family. ${ }^{253}$

249. See generally EdgaRdo Buscaglia \& William E. RatLIFF, THE LAW AND ECONOMICS OF DEVELOPMENT (1997).

250. Japan, a frontrunner in adaptive reception of modemized institutions, is introducing graduate legal education influenced by American law. See Shozo Ota \& Kahei Rokumoto, Issues of the Lawyer Population: Japan, 25 CASE W. RES. J. INT'L L. 315 (1993). Such reformas are in advanced phase of implementation. See Symposyunm on Japanese Law, 49 AM. J. COMP. L. 545 (2001).

251. See NADER, supra note 154 ; $c$ f. CHOMSKY, supra note 66.

252. See generally HARDT \& NEGRI, supra note 10 (describing the idea of globalization as empire); SUSAN Strange, The Retreat Of THE State: THE Diffusion OF POWER IN THE WORLD ECONOMY (1996) (discussing the competing but complementary idea of globalization as Americanization).

253. Oppression by means of "harmony ideology," is gaining currency in Europe, where false arguments in favor of weak consumers accompany the proliferation of suggestions of altemative forums for efficient disposal of consumer's disputes. It is apparent, however, that the mediation alternative in unbalanced power contexts sacrifices the interests of the weak for those of the strong. Corporate international market players highly value predictability of damage awards such as those stemming from the emasculation of juries and from the outcomes of mediation because predictability makes the costs easily transferable to consumers and easily insurable. See LAURA NADER, HARMONY IDEOLOGY: JUSTICE AND CONTROL IN A ZAPOTEC MOUNTAN VILLAGE (1990) (explaining the notion of Harmony Ideology as a controlling process); see also NADER, supra note 154. Interestingly, the European Commission has just produced a White Paper suggesting extensive introduction of ADR in European consumer law. By so doing corporate actors can "cap" their liability by transferring the costs of accidents to consumers, though only of those accidents occurring within Europe. 
In the academic domain, a very similar philosophy, labeled as an upgrading of obsolete positivistic modes of thought, is visible in the creation of a strong and prestigious conservative scholarly critique of the politically legitimate sources of law. Such critique, in order to show the efficiency of marketfriendly reactive institutions (and of the common-law process) has accused proactive institutions such as legislatures or administrative agencies of being captured by lobbyists' money. ${ }^{254}$ This idea is orthodox in those U.S. law and economics circles that have been able to gain major influence in framing the international financial institutions' development plans for the Third World. It is by no means absent in Europe today. ${ }^{255}$

Imperial law copes with the resistance coming from legal path dependency by producing a new generation of lawyers, cosmopolitan in their training and exposed to the new institutional setting of imperial law, to substitute for the old (path dependent and resisting) professionals in whatever project is important to global capital. ${ }^{256}$ Dualism, discussed in the development literature devoted to the economics of the Third World, is now a particularly useful notion in understanding changes in the global legal profession. ${ }^{257}$ Local lawyers, incapable of expressing themselves in English, although often more skilled and

\footnotetext{
254. See Kennedy, supra note 114 (providing a critical discussion of the politically conservative background of law and economics).

255. Such an attitude that considers "legal science" as neutral and insulated from capture is similar to the classic law and economics attitude that considers the "common law process" insulated. But such an idea is no more robust (or less arbitrary) in the old continent than it is in the United States. The high degree of insulation of U.S. courts by law that should shield them from any risk of capture is only accepted as an article of faith by mainstream American legal culture (the prestige of Article III of the U.S. Constitution is tremendous). There is no empirical testing whatsoever regarding the effectiveness of the insulation devices provided by Article III of the U.S. Constitution for the members of the federal judiciary (concerning tenure of office and guaranteed salary). Such position is taken by a variety of scholars, such as C. Kirchner, Roger Van den Bergh, and Hugh Collins. See C. Kirchner, An Optionan European Civil Code: Initiating a Learning Process, in AN ACADEMIC GREEN PAPER ON EuROPEAN CONTRACT LAW 399 (Stefan Grundman \& Jules Stuyk eds., 2002) [hereinafter GREEN PAPER]; Roger Van den Bergh, Forced Harmonisation of Contract Law in Europe: Not to Be Continued, in GREEN PAPER, supra note 255; Hugh Collins, Transaction Costs and Subsidiarity in Eurpoean Contract Law, in GREEN PAPER, supra note 255. But such normative use of a biased version of law and economics is even more dangerous in the European legal landscape than in the United States. See generally DUNCAN KENNEDY, The Political Stakes in "Merely Technical" Issues of Contract Law, 10 EUR. REV. PRIV. LAW 7 (2002).

256. See R. Abel, The Promise and Peril of International Order, in TRANSNATIONAL Legal Processes, supra note 1 , at 213 .

257. Indeed this phenomenon in the domain of the law is the perfect equivalent of the impact on local distribution (small business and so forth) of the international chains of massive distribution increasingly swallowing a large sphere of what used to be local business. See Mauro Bussani \& Ugo Mattei, Making the Other Path Efficient: Economic Analysis and Tort Law in Less Developed Countries, I CARDozo EL. L. BUL. 8, 3.4 (1995) http://www.jus.unitn.it/cardozo/Review/Torts/Matteil.html.
} 
experienced than the emerging elite, are confined to an increasingly shrinking local sector, dealing with the less important and prestigious aspects of legal business. The increasing presence of transnational law firms through the world is perfect evidence of such dualism, something that limits the resisting impact of legal path dependency by incrementally reducing its sphere of relevance. By penalizing the more senior members of the local legal professions outside of the United States, the cultural and linguistic gap is creating a real issue of access to law. ${ }^{258}$

Imperial law penetrates worldwide, with its reactive philosophy, its rhetoric of legality, and its practice of oppression. ${ }^{259}$ The current relationship between the Western legal tradition and contexts of alternative legality (most notably but not limited to Islamic law) is a fascinating example of the way in which legal Americanization is transformed into legal Empire. The features of American law that get incorporated into imperial law are the spectacular ones, and the features that do not fit the spectacular picture are simply dismissed or ignored as non-legal. American law is then ceasing to be a real legal system, with a local history, local concerns, and local shames, concretely governing the social relationships among the population living within its jurisdictional boundaries. American law is instead transformed into a show and assumes an eternally present imperial identity that puts it beyond the issue of compatibility with possibly incompatible local contexts and circumstances. Recent scholarship, in such different contexts as Latin America and China, has denounced the strategy by which this imperial legal identity has been obtained. Scholarship in the tradition of "law and development" has constantly stressed the "gap"- the lack of "real law"-in Latin America. ${ }^{260}$ Developing on the idea of Orientalism as proposed by Edward Said, recent scholarly accounts of general legal history, as well as of developments in Chinese law, ${ }^{261}$ have pointed out the process of delegalization of non-western legal traditions. This very same strategy of

258. This is a phenomenon perhaps similar to that of unequal access to authority due to differences in size of libraries, once well documented in the United States by Professor Merryman, and now successfully solved, at least in the United States, by the diffusion of Lexis and Westlaw. See generally John Henry Merryman, The Authority of Authority: What the California Supreme Court Cited in 1950,6 STAN. L. REV. 613,613 (1954).

259. Blackmail by international financial institutions is today the main method of using the advantages of imperial law. This is scarcely a new phenomenon. Modernization projects have been based on blackmail through the history of legal transplants, with notable examples in early twentieth century China and Japan. Blackmail has been recently re-named the "context of conditionality." See Moore, supra note 22.

260. See Jorge Esquirol, Paper Presented at the Harvard Conference on Critical Globalization (Apr. 12, 2002).

261. See Monateri, supra note 128; see also Teemu Ruskola, Legal Orientalism, 101 MICH. L. REV. (forthcoming 2002). 
spectacular de-legalization of alternative contexts of legality is even more visible in contexts whose resistance to the "integrated spectacle" is stronger and is perceived as more dangerous. The campaign for the promotion of human rights and of woman's equality ${ }^{262}$ in Islamic societies, based on the one-sided and spectacular emphasis on a few aberrant practices and episodes by means of extensive media coverage, is a plain attempt to substitute local legal and political legitimacy with the imperial one. ${ }^{263}$ Horrific episodes of brutality in the way in which the law is enforced and applied are unfortunately common at the very center of the legal Empire. ${ }^{264}$

The imperial ideal, as produced by the spectacular society, cannot be challenged by historical accounts of political failures of any kind, whether located at the center or at the periphery. Within the logic of the integrated spectacle, to use the reality of the U.S. legal system as a way to challenge the imperial ideal of democracy and the rule of law makes no sense. It would be exactly the same thing as attempting to challenge the suburban family dream of middle America as it appears in the advertising of minivans, mortgage plans, or life insurance policies by using the high rate of vicious divorce litigation or the miserable conditions of dispossessed homeowners that have defaulted in paying the mortgage installment. ${ }^{265}$

What is the fate of political resistance, of counter-hegemonic forces within this scenario? To be sure, one should be careful to distinguish the theory from the practice. The generalized belief of the spectacular world seems to be that military technology and violence will be able to defeat demography. We are bound to be awakened from this denial. Demography has always overwhelmed military technology, particularly when the distribution of resources that such

262. One should consider the brilliant insight of Camille Paglia, that stiletto heels are the Western version of Chinese foot binding in a population of women obsessed by the male constructed myth of beauty. See Camille Paglia, SeX, ART ANd AMERICAN CUlture 145-46 (1992); see also NaOMI WOLF, The Beauty MYTH: HOW IMAGES OF BEAUTY ARE USED AGAINST WOMEN (1992).

263. See Obiora, supra note 70.

264. One only has to name them, from the "suicide" of political opponents in German and Italian jails, to the prisoners' conditions at Guantanamo, to the execution of the mentally retarded and minors in the United States, to the "suspension" of human rights in Ireland, in the Palestinian territories, or even in Genoa right under the windows of the leaders of the integrated spectacle, gathering together in one of the G8 meetings.

265. In the process of transformation from "American law" into "spectacular imperial law," the role of the movie industry and of the international mass media has been enormous. Both the professional branches that make the "reactive" model of governance the essence of imperial law have been receiving their share of Hollywood attention. While Julia Roberts in Erin Brokovich can be seen as the most symbolic testimonial of the opportunities that courts of law can offer to a Western woman fighting for the good cause, Legally Blond and $A$ Beautiful Mind stage the wonderful objective fairness of the most prestigious chains of transmission of global knowledge in the Imperial world: the U.S. academia and the Nobel Committee. 
violence sustains is in the interest of the very few and makes the vast majority very unhappy. In history, the rules of the game that favor the few have always been changed, either incrementally or by means of revolution. ${ }^{266}$

What I have labeled as the Latin resistance has been itself largely incorporated into the show, geographically displaced and deeply transformed by its acceptance and assimilation in the discursive practices of the mainstream academy. The strategy used to reach this result has been once again that of decontextualization. Anybody who has learned a lesson from the need to use context in order to make significant comparisons is able to see the existence of an American Foucault different from the French Foucault, an American Gramsci different from an Italian Gramsci, and an American Althusser different from a French Althusser. The context of production is plainly ignored, so that, out of context, what is left is only the spectacular side of any theory. The nature of "grand theory" and of "revolutionary practice" of the work of such thinkers has been almost entirely cancelled by a variety of post-modernist discursive strategies able to go as far as analyzing within one framework such radically different political messages as "neo-pragmatism" in law and economics and many of the second generation narratives of critical legal studies. ${ }^{267}$

Once assimilated by the context of reception (the American pluralist academic discourse), and applied for the first time to the analysis of the (reactive) legal institutions as they appear in the American receiving context, the Latin resistance gets exported once again in the new and old periphery, deeply transformed in political meaning and significantly de-radicalized. What use, if any, the new radical elites in the periphery will be able to make of such theories is an issue open for discussion.

Political radicalism and polarization are the foes of the show society, which needs broad areas of relative social peace in order to further develop the boundaries of the global unrestricted market. Attempts to change the course of events, to protest and expose the "natural evolution," that have led to the present state of imperial dualism are either demonized or dismissed as naïve.

266. The American Revolution is one of the most fascinating examples from this perspective. The chances of success against the almighty British army were not high and they were not perceived as such by the main revolutionary actors. See ELLIS, supra note 29. Hence, there is still room to dream of a revolution originating in less developed countries. The survival of leaders such as Hugo Chavez in South America, or movements giving birth to the African Union in order to solve the problem of intemal warfare, might all be signs of hope. See Fidel Castro, We Either Unite or We Die, in DEMOCRATIZNG THE GLOBAL ECONOMY, supra note 230, at 74.

267. See generally MINDA, supra note 116. 
Whether genuine counter-hegemonic forces will be able to modify the present path of imperial globalization with new forms of political and economic struggle capable of re-asserting effective legal (and political) control over unlimited exploitive patterns is an open question that is in urgent need of an effective answer. The exploitation of the world commons is rapidly approaching tragic outcomes. ${ }^{268}$

268. See G. Hardin, supra note 13 , at 1243. 